\title{
The Preparation and Characterisation of Rhodium(III) and
} Iridium(III) Half Sandwich Complexes with Napthalene-1,8dithiolate, Acenaphthene-5,6-dithiolate and Biphenyl-2,2'dithiolate

Phillip S. Nejman, Brian Morton-Fernandez, Nicholas Black, David B. Cordes Alexandra M. Z. Slawin, Petr Kilian and J. Derek Woollins

\begin{abstract}
The synthesis of rhodium(III) and iridium (III) half sandwich complexes [Cp*M(PEt 3 )(S-R-S)], $M=R h, I r ; S-R-S=$ naphthalene-1,8-dithiolate $\left(\right.$ NaphthS $\left._{2}, a\right)$, acenaphthene-5,6-dithiolate $\left(\right.$ AcenapS $_{2}$, b) and biphenyl-2,2'-dithiolate $\left(\right.$ BiphenS $\left._{2}, \mathbf{c}\right)$ is reported. We also describe the isolation of a new compound acenaphthene-1,8-dithiol. All complexes have been fully characterised using multinuclear NMR spectroscopy and single crystal X-ray diffraction. The ligands naphthalene-1,8-dithiol $\left(\mathbf{H}_{\mathbf{2}} \mathbf{a}\right)$, acenaphthene-1,8-dithiol $\left(\mathbf{H}_{\mathbf{2}} \mathbf{b}\right), 1, \mathbf{1}^{\prime}$-biphenyl-2,2'dithiol $\left(\mathbf{H}_{\mathbf{2}} \mathbf{C}\right)$ and benzene-1,2-dithiol $\left(\mathbf{H}_{\mathbf{2}} \mathbf{d}\right)$ have also been characterised by single crystal $\mathrm{X}$ ray diffraction.
\end{abstract}

\section{Introduction}

The coordination of $S, S$ bidentate ligands remains an important area of chemistry. Complexes bearing this type of ligand have a number of industrial applications including vulcanisation[1-4], lubricant additives[5] and catalysis.[1-4] In addition S,S donors can support unusual magnetic properties and are important in biological systems. [6] As part of our interest in the properties of sulfur donor systems we have investigated a series of dithiolate ligands bound to aromatic backbones. 
There has been little study on the coordination chemistry of these types of ligands thus far. One exception to this is the work by Teo and co-workers carried out in the late 1970s and early $1980 \mathrm{~s}$ on the oxidative addition of tetrathionaphthalene (TTN), tetrachlorotetrathionaphthalene (TCTTN) and tetrathiotetracene (TTT) to a variety of low valent metal substrates (Figure 1).[7-14] Another interesting system bearing the related hexachlorodithionaphthalene (HCDTN) resulted in an unusual trinuclear nickel complex $\left[\mathrm{Ni}_{3}\left(\mathrm{PPh}_{3}\right)_{3}\left(\mathrm{~S}_{2} \mathrm{C}_{10} \mathrm{Cl}_{6}\right)_{3}\right]$ with the HCDNT acting as a bridging ligand.[15]<smiles>c1cc2c3c(ccc4c3c1SS4)SS2</smiles>

TTN<smiles>Clc1c(Cl)c2c3c(c(Cl)c(Cl)c4c3c1SS4)SS2</smiles>

TCTTN<smiles></smiles>

TTT<smiles>ClC1=C(Cl)c2c(Cl)c(Cl)c(Cl)c3c2SC3=C1Cl</smiles>

HCDTN

Figure 1. Structurally related aromatic sulfur donating ligands

More recently there has been an interest in using naphthalene-1,8- and 1,1'-biphenyl-2,2'dithiolate based ligands bound to iron as electron transfer catalysts designed to mimic iron hydrogenases (Figure 2).[16-21] The structurally related compound acenaphthene-5,6dithiolate is less well documented with only one example of complexes incorporating this type of ligand out with our research.[22] Topf and co-workers have used the acenaphthene backbone as a linker between a 1,2-diimine unit and a dithiolate binding site. The iron carbonyl complex bearing this ligand was shown to have potential as a multielectron transfer photosensitiser for artificial photosynthesis and as a bio-inspired photoredox catalyst.[22]

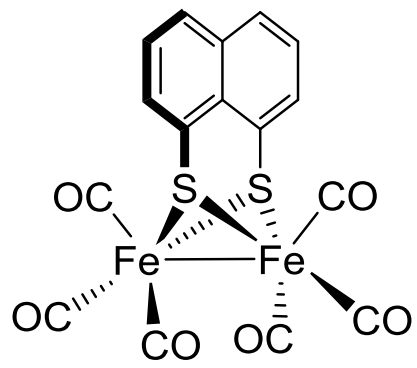

Figure 2. An iron dithiolato complex active in electron transfer processes 
With the exception of the electron transfer mimics the coordination chemistry of $1,1^{\prime}$ biphenyl-2,2'dithiolate has seen little investigation. Two molybdenum based complexes have been synthesised with one bearing an Mo oxygen triple bond.[23, 24] A derivatised version of the ligand has been bound to copper[25] with mono- and dinuclear nickel complexes also reported.[26] There has also been two reports on methods to synthesise titanocene-2,2'-dithiolatobiphenyl.[27, 28]

Herein we describe the synthesis of a series of dithiolato complexes bound to rhodium(III) and iridium(III) metal centres. We also report the isolation of a new dithiol, acenaphthene1,8-dithiol, along with crystallographic studies of naphthalene-1,8-dithiol, 1,1'-biphenyl-2,2'dithiol and benzene-1,2-dithiol. All new complexes and the new dithiol have been fully characterised principally by multinuclear NMR spectroscopy, elemental analysis and single crystal X-ray diffraction.

\section{Results and Discussion}

The diprotic pro-ligands naphthalene-1,8-dithiol [Naphth $\left.(\mathrm{SH})_{2}\right]\left(\mathbf{H}_{\mathbf{2}} \mathbf{a}\right)$, acenaphthene-5,6dithiol $\left[\operatorname{Acenap}(\mathrm{SH})_{2}\right] \quad\left(\mathbf{H}_{\mathbf{2}} \mathbf{b}\right)$ and 1,1'-biphenyl-2,2'-dithiol [Biphen $\left.(\mathrm{SH})_{2}\right] \quad\left(\mathbf{H}_{\mathbf{2}} \mathbf{C}\right)$ were synthesised from their respective disulfides naphtho[1,8-cd]-1,2-dithiole,[32] 5,6dihydroacenaphtho[5,6-cd]-1,2-dithiole[31] and dibenzo[c,e]-1,2-dithiin[33] (Scheme 1). The reduction of disulfides was performed using $\mathrm{NaBH}_{4}$,[34] which was followed by an acidic workup after which all three pro-ligands were isolated as colourless solids, each possessing only a mild thiol odour. Benzene-1,2-dithiol $\left(\mathbf{H}_{\mathbf{2}} \mathbf{d}\right)$ was prepared according to literature and purified by distillation to afford a colourless liquid with a strong thiol odour (Scheme 1).[35] $\mathbf{H}_{\mathbf{2}} \mathbf{a}, \mathbf{H}_{\mathbf{2}} \mathbf{C}$ and $\mathbf{H}_{\mathbf{2}} \mathbf{d}$ were isolated and spectroscopically characterised earlier, $[33,34,36]$ for completeness we report their $\mathbf{X}$-ray structures here. In contrast, $\mathbf{H}_{\mathbf{2}} \mathbf{b}$ was not isolated previously, and we report full spectral characterisation as well as its X-ray structure. 
<smiles>c1cc2c3c(cccc3c1)SS2</smiles>

i)<smiles>Sc1cccc2cccc(S)c12</smiles><smiles>c1cc2c3c(ccc4c3c1CC4)SS2</smiles>

i)<smiles>Sc1ccc2c3c(ccc(S)c13)CC2</smiles><smiles>c1ccc2c(c1)SSc1ccccc1-2</smiles>

i)<smiles>Sc1ccccc1-c1ccccc1S</smiles>

\section{$\mathrm{H}_{2} \mathrm{C}$}<smiles>Sc1ccccc1Sc1ccccc1S</smiles>

Scheme 1. Synthesis of pro-ligands $\mathbf{H}_{\mathbf{2}} \mathbf{a}-\mathbf{H}_{\mathbf{2}} \mathbf{d}$. Conditions: i) 1. $\mathrm{NaBH}_{4}, \mathrm{EtOH} / \mathrm{THF}, 0{ }^{\circ} \mathrm{C} .2$. $\mathrm{HCl}(\mathrm{aq})$. ii) 1. $n$-BuLi, TMEDA, hexane, $0^{\circ} \mathrm{C}$. 2. $\mathrm{S}_{8},-20^{\circ} \mathrm{C}$. 3. $\mathrm{HCl}(\mathrm{aq})$.

Acenap $(\mathrm{SH})_{2}\left(\mathbf{H}_{\mathbf{2}} \mathbf{b}\right)$ was isolated as a pale brown solid, and was fully characterised by ${ }^{1} \mathrm{H},{ }^{13} \mathrm{C}\left\{{ }^{1} \mathrm{H}\right\}$ NMR spectroscopy, ES-MS, IR, Raman and X-ray crystallography. The compound was found to be air stable with no decomposition observed over several months whilst storing in air. For our purposes the compound didn't require further purification, however analytically pure colourless crystalline material was obtained after recrystallization from boiling hexane; the homogeneity was verified by microanalysis. The ${ }^{1} \mathrm{H}$ NMR spectrum of $\mathrm{H}_{2} \mathbf{b}$ (in $\mathrm{CDCl}_{3}$ ) shows the distinctive thiol peak at $\delta=4.16 \mathrm{ppm}$ and the aromatic protons as a set of partially overlapping doublets centred at $\delta=7.47$ and $7.09 \mathrm{ppm}$, while the signal from the alkyl bridge can be seen as a broad singlet at $\delta=3.31 \mathrm{ppm}$. The ${ }^{13} \mathrm{C}\left\{{ }^{1} \mathrm{H}\right\} \mathrm{NMR}$ spectrum showed the expected signals including all the quaternary carbons. A medium intensity band at $2546 \mathrm{~cm}^{-1}$ in the Raman spectrum and a weak band at $2510 \mathrm{~cm}^{-1}$ in the IR spectrum correspond to $v(\mathrm{~S}-\mathrm{H})$ vibrations. The mass spectrum $\left(\mathrm{ES}^{-}\right)$shows the parent ion at $\mathrm{m} / \mathrm{z} 217$ corresponding to the loss of $\mathrm{H}^{+}$. 
Starting dichloro complexes [Cp* $\left.\mathrm{RhCl}_{2} \mathrm{PEt}_{3}\right]$ (1) and [Cp* $\left.\mathrm{ICCl}_{2} \mathrm{PEt}_{3}\right]$ (2) were prepared according to literature procedures.[37, 38] The ${ }^{31} \mathrm{P}\left\{{ }^{1} \mathrm{H}\right\}$ NMR spectra of $\mathbf{1}$ and $\mathbf{2}$ showed peaks at $\delta=28.2 \mathrm{ppm}$ and $\delta=-5.8 \mathrm{ppm}$ respectively with the corresponding ${ }^{1} \mathrm{JPh}_{\mathrm{Ph}}$ coupling of $138 \mathrm{~Hz}$ observed for $\mathbf{1}$ (Table 1). For completeness, we report X-ray crystal structures of 1 and $\mathbf{2}$ as these were not reported previously.

The synthesis of $\left[\mathrm{Cp} * \mathrm{Rh}\left(\mathrm{NaphthS}_{2}\right) \mathrm{PEt}_{3}\right] \quad(3 \mathrm{a}), \quad\left[\mathrm{Cp} * \mathrm{Rh}\left(\right.\right.$ AcenapS $\left.\left._{2}\right) \mathrm{PEt}_{3}\right]$ (3b), $\left[\mathrm{Cp}^{*} \mathrm{Rh}\left(\right.\right.$ BiphenS $\left.\left._{2}\right) \mathrm{PEt}_{3}\right]$ (3c), $\left[\mathrm{Cp} * \operatorname{Ir}\left(\right.\right.$ NaphthS $\left.\left._{2}\right) \mathrm{PEt}_{3}\right]$ (4a), [Cp*Ir(AcenapS 2$\left.) \mathrm{PEt}_{3}\right]$ (4b) and $\left[\mathrm{CP}^{*} \operatorname{Ir}\left(\right.\right.$ BiphenS $\left.\left._{2}\right) \mathrm{PEt}_{3}\right](\mathbf{4 c})$ are shown in Scheme 2. The metathesis of the chloride ligands with the dithiol ligands proceeds smoothly in refluxing THF. The presence of the phosphine group allowed for easy monitoring of the progress of the reaction by ${ }^{31} \mathrm{P} N M R$ spectroscopy. When first mixed a cloudy solution forms which after refluxing becomes clear. The reaction proceeds with loss of hydrogen chloride; despite no trapping agent being used good isolated yields were obtained (75-83\% after purification). In all cases purification was performed by column chromatography on silica using dichloromethane as the eluent.

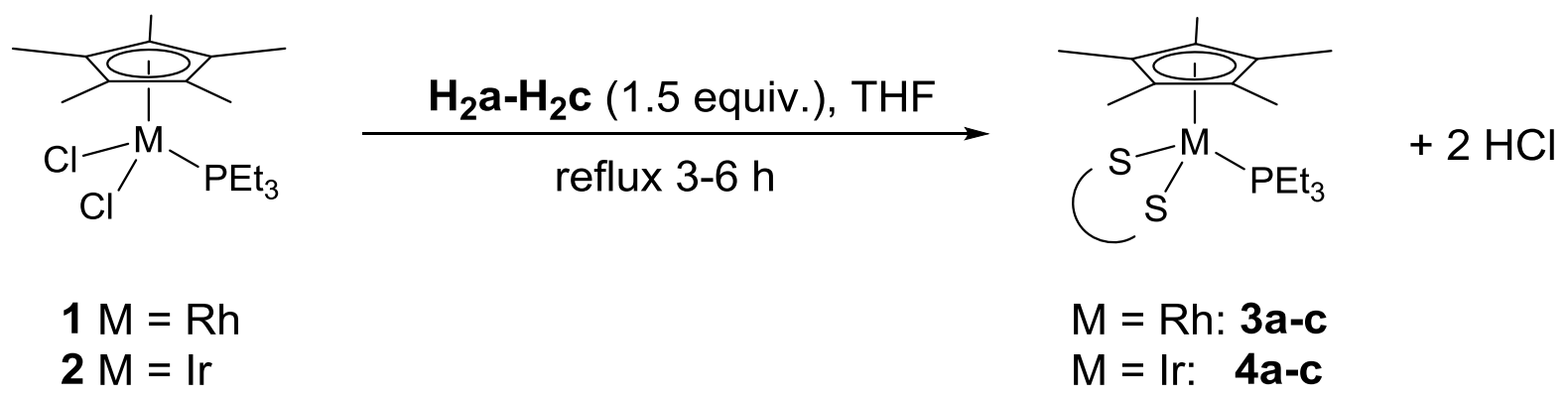<smiles>Sc1cccc2cccc(S)c12</smiles>

a<smiles>Sc1ccc2c3c(ccc(S)c13)CC2</smiles>

b<smiles>Sc1ccccc1-c1ccccc1S</smiles>

C

Scheme 2. General reaction conditions for the synthesis of $\mathbf{3 a - c}$ and $\mathbf{4 a - c}$.

The ${ }^{31} \mathrm{P}\left\{{ }^{1} \mathrm{H}\right\}$ NMR data $\left(\mathrm{CDCl}_{3}\right)$ for complexes $\mathbf{1}, \mathbf{2}, \mathbf{3 a}-\mathbf{c}$ and $\mathbf{4 a}-\mathbf{c}$ are shown in Table 1. For complexes $3 a-c$ there is a slight upfield shift in the ${ }^{31} \mathrm{P} N M R$ spectra compared to the 
starting complex 1 ( $\Delta \delta=3.3$ to $6.3 \mathrm{ppm}$ ), the coordination of the dithiolate ligand is also accompanied by a small increase in the ${ }^{1} J_{\text {RhP }}$ coupling in $\mathbf{3 a}-\mathbf{c}$ compare to $\mathbf{1}$.

The ${ }^{1} \mathrm{H}$ NMR spectra $\left(\mathrm{CDCl}_{3}\right)$ of $3 \mathrm{a}-\mathrm{c}$ show the aromatic ligand backbone signals in the range of 7.86-6.68 ppm. The $\eta^{5}-\mathrm{Cp}^{*}$ signals (1.52-1.45 ppm, $\mathrm{CH}_{3}$ groups) are split into doublets by the long range phosphorus coupling $\left({ }^{4} J_{\mathrm{HP}}=2.7-2.9 \mathrm{~Hz}\right)$. The ethyl groups show multiplets for the $\mathrm{CH}_{2}$ groups and doublet of triplets for the $\mathrm{CH}_{3}$ groups in $\mathbf{3 a}$ and $\mathbf{3 b}\left({ }^{3} J_{\mathrm{HP}}=\right.$ $15.8 \mathrm{~Hz},{ }^{3} \mathrm{~J}_{\mathrm{HH}}=7.8 \mathrm{~Hz}$ ). Interestingly, the two $\mathrm{CH}_{2}$ hydrogen atoms in $3 \mathrm{c}$ are anisochronous, displaying two distinct complex multiplets $[2.04-1.86(\mathrm{~m}, 3 \mathrm{H})$ and $1.73-1.58(\mathrm{~m}, 3 \mathrm{H})]$. This is likely to be the result of the restricted rotation or aryl-aryl bond in the biphenyldithiolate ligand, which introduces an axis of chirality, thus making the two $\mathrm{CH}_{2}$ protons in $3 \mathbf{c}$ diastereotopic. As expected, the ${ }^{13} \mathrm{C}\left\{{ }^{1} \mathrm{H}\right\}$ NMR spectra displays only one signal corresponding to the ethyl $\mathrm{CH}_{2}$ carbons in each of the complexes $\mathbf{3 a - c}$. The mass spectra (ES+ for $\mathbf{3 a} \mathbf{a}-\mathbf{b}$, $\mathrm{APCl}+$ for $3 \mathrm{c}$ ) show the $\left[\mathrm{M}+\mathrm{H}^{+}\right]$ions at $m / z 547,573$ and 573 , respectively. Purity of the new complexes 3a-c was verified by microanalysis.

Table 1. ${ }^{31} \mathrm{P}\left\{{ }^{1} \mathrm{H}\right\}$ NMR data $\left(\mathrm{CDCl}_{3}\right)$ for complexes $\mathbf{1}, \mathbf{2}, \mathbf{3 a}-\mathbf{c}$ and $\mathbf{4 a - c}$. All $\delta$ values are in ppm and $J$ values in hertz.

\begin{tabular}{lllll}
\hline & $\mathbf{1}$ & $\mathbf{3 a}$ & $\mathbf{3 b}$ & $\mathbf{3 c}$ \\
\hline$\delta_{\mathrm{P}}$ & 28.2 & 24.6 & 24.9 & 21.9 \\
$1 J_{\mathrm{PRh}}$ & 137.5 & 146.7 & 145.9 & 150.8 \\
\hline & $\mathbf{2}$ & $\mathbf{4 a}$ & $\mathbf{4 b}$ & $\mathbf{4 c}$ \\
\hline$\delta_{\mathrm{P}}$ & -5.8 & -13.9 & -14.4 & -15.5 \\
\hline
\end{tabular}

The ${ }^{31} \mathrm{P}\left\{{ }^{1} \mathrm{H}\right\}$ NMR spectra $\left(\mathrm{CDCl}_{3}\right)$ of complexes $4 \mathrm{a}-\mathrm{c}$ (Table 1$)$ also exhibit an upfield shift compared to the starting complex 2 ( $\Delta \delta=8.1$ to $9.7 \mathrm{ppm}$ ). While the upfield shift in the iridium series is slightly larger compared to that of the rhodium analogues, less variation is observed between the complexes $4 a-c$. The ${ }^{1} \mathrm{H}$ NMR spectra of $4 \mathbf{a}-\mathrm{c}(\mathrm{CDCl} 3)$ show the same pattern as the rhodium analogues, including the anisochronicity of the $\mathrm{CH}_{2}$ (ethyl) hydrogens in $4 \mathrm{c}\left[\delta_{\mathrm{H}} 2.05-1.87(\mathrm{~m}, 3 \mathrm{H}), 1.73-1.56(\mathrm{~m}, 3 \mathrm{H})\right]$ (see above for discussion of the same feature in $\mathbf{3 c}$ ). The mass spectra (ES+ for $\mathbf{4 a}$ and $\mathbf{4 b}, \mathrm{APCl}^{+}$for $\mathbf{4 c}$ ) show the $\left[\mathrm{M}+\mathrm{H}^{+}\right]$ions at $m / z$ 637, 663, 663 respectively. Peaks corresponding to the loss of $\mathrm{PEt}_{3}$ group are also 
observed and in the case of $\mathbf{4 a}$ and $\mathbf{4 b}$ these are base peaks. Once again the IR and Raman spectra showed the expected bands and excellent microanalysis data were obtained for $\mathbf{4 a -}$ c.
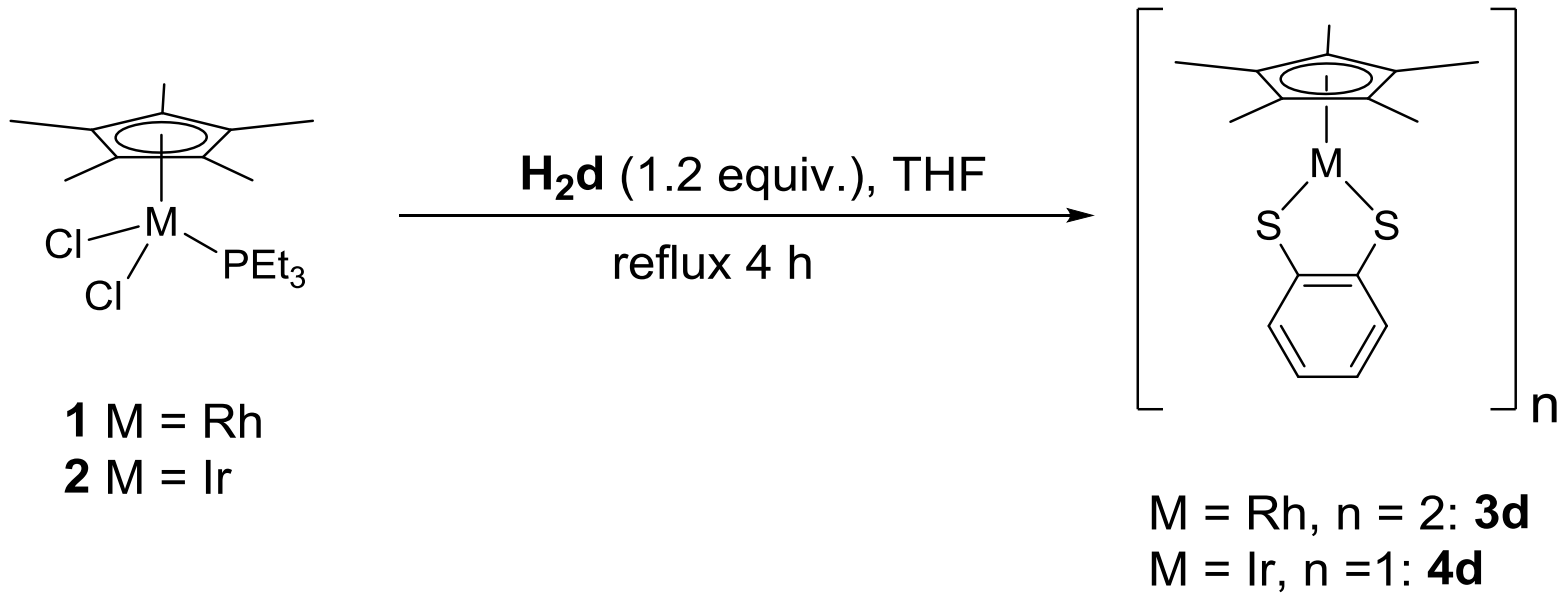

Scheme 3. Reaction conditions for the synthesis of $\mathbf{3 d}$ and $\mathbf{4 d}$

Interestingly in contrast to the above examples, the reaction between benzene-1,2dithiol and complexes $\mathbf{1}$ and $\mathbf{2}$ resulted in $\mathbf{3 d}$ and $\mathbf{4 d}$ (Scheme 3 ) that have been previously reported by $\mathrm{Xi}$ and co-workers.[39] This was confirmed by ${ }^{1} \mathrm{H}$ and ${ }^{13} \mathrm{C}$ NMR spectroscopy in addition to elemental analysis. We have no ready explanation for this difference in reactivity.

\section{X-ray Crystallography}

\section{Pro-ligands $\mathrm{H}_{2} \mathrm{a}-\mathrm{d}$ and Dichloro Complexes 1 and 2}

Despite $\mathbf{H}_{\mathbf{2}} \mathbf{a}$ /c/d being reported and spectroscopically characterised previously no X-ray crystal data has been published. The solid state structures of the pro-ligands $\mathbf{H}_{\mathbf{2}} \mathbf{a}-\mathbf{H}_{\mathbf{2}} \mathbf{d}$ are shown in Figure 3, with selected structural parameters of $\mathbf{H}_{\mathbf{2}} \mathbf{a} / \mathbf{b}$ in Table 2 and $\mathbf{H}_{\mathbf{2}} \mathbf{c} / \mathbf{d}$ in Table 3. There are two molecules within the asymmetric unit for $\mathbf{H}_{\mathbf{2}} \mathbf{a} / \mathbf{b} / \mathbf{d}$ with four present in $\mathbf{H}_{2} \mathbf{c}$. When compared to the respective disulfide, the $\mathrm{S} \cdots \mathrm{S}$ distances have increased by ca. 1.0-1.2 $\AA$ in $\mathbf{H}_{2} \mathbf{a}$ /b as the bonding interaction is replaced by a repulsive one.[40, 41] These observations are confirmed by the splay angles, with the dithiols having a positive values of 10.4(9)-11.8(9) ${ }^{\circ}$ and $15.9(9)-20.5(9)^{\circ}$ in $\mathbf{H}_{\mathbf{2}} \mathbf{a}$ and $\mathbf{H}_{\mathbf{2}} \mathbf{b}$ respectively compared to negative values in their corresponding disulfides. The increase in the $S \cdots S$ distance is larger in $\mathbf{H}_{\mathbf{2}} \mathbf{C}$ (1.65-2.67 $\AA$ ) as the rotation around the aryl-aryl bond allows the sulfur atoms to lie further 
apart. Interestingly the S...S distance (3.068(1) $\AA$ ) in $\mathbf{H}_{\mathbf{2}} \mathbf{d}$ is between that seen in the other two planar ligands despite being ortho substituted. The splay angle has a small negative value indicating a slight attractive force between the two sulfur atoms.
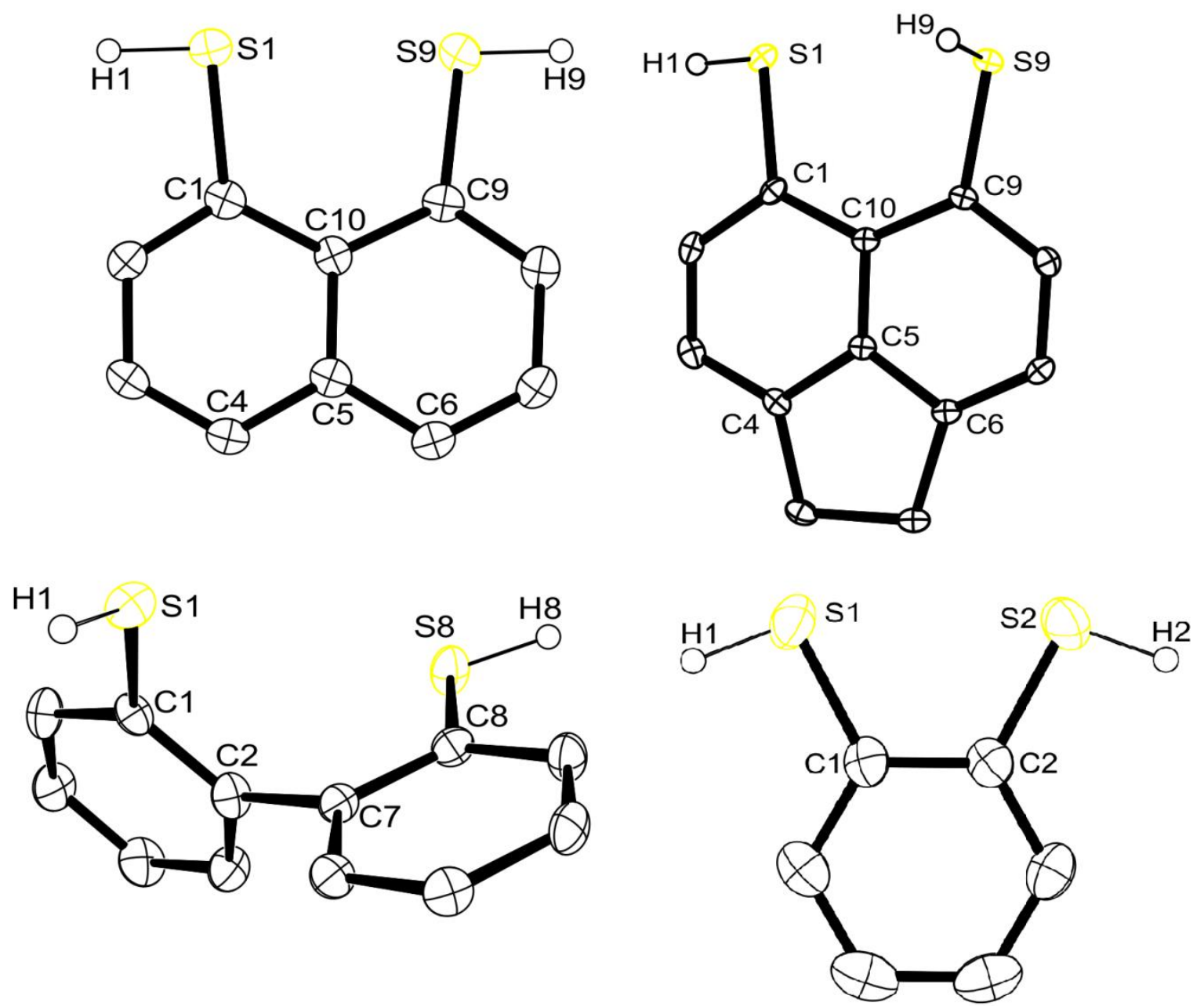

Figure 3. Displacement ellipsoid representation of $\mathbf{H}_{\mathbf{2}} \mathbf{a}$ (Top left), $\mathbf{H}_{\mathbf{2}} \mathbf{b}$ (Top right), $\mathbf{H}_{\mathbf{2}} \mathbf{C}$ (Bottom left) and $\mathbf{H}_{\mathbf{2}} \mathbf{d}$ (Bottom right). Carbon-bound hydrogen atoms are omitted for clarity, only one of the four independent molecules is drawn for $\mathbf{H}_{\mathbf{2}} \mathbf{C}$

The torsion angle $S(1)-C(1) \cdots C(9)-S(9)$ has increased in both $\mathbf{H}_{\mathbf{2}} \mathbf{a}$ and $\mathbf{H}_{\mathbf{2}} \mathbf{b}$ by $5.2-6.1^{\circ}$ and $1.1-2.6^{\circ}$ respectively compared to their corresponding disulfides, indicating a mild but noticeable out of plane displacement. The torsion angle between the phenyl rings in $\mathbf{H}_{\mathbf{2}} \mathbf{C}$ varies at $-79.8^{\circ},-82.7^{\circ}$ and $-102.1^{\circ}$, which suggests the ideal position for the rings to sit is approximately $10-12^{\circ}$ off perpendicular. 
Table 2. Selected bond lengths $[\AA]$, angles $\left[^{\circ}\right]$ and displacements $[\AA]$ for $\mathbf{H}_{\mathbf{2}} \mathbf{a}$ and $\mathbf{H}_{\mathbf{2}} \mathbf{b}$.

\begin{tabular}{lll}
\hline & $\mathbf{H}_{2} \mathbf{a}$ & $\mathbf{H}_{2} \mathbf{b}$ \\
\hline $\mathrm{S}(1)-C(1)$ & $1.788(3)[1.786(5)]$ & $1.785(4)[1.782(4)]$ \\
$\mathrm{S}(9)-C(9)$ & $1.784(3)[1.786(5)]$ & $1.788(4)[1.788(4)]$ \\
$\mathrm{S}(1) \cdots \mathrm{S}(9)$ & $2.951(2)[2.919(2)]$ & $3.104(1)[3.264(2)]$ \\
$\mathrm{C}:(1)-(10)-(5)-(6)$ & $176.8(3)[176.9(4)]$ & $178.9(3)[179.4(3)]$ \\
$\mathrm{C}:(9)-(10)-(5)-(4)$ & $178.3(3)[178.4(4)]$ & $178.0(3)[177.0(3)]$ \\
$\mathrm{S}(1)-C(1) \cdots C(10)-S(9)$ & $5.4(2)[6.3(2)]$ & $3.0(2)[1.5(2)]$ \\
$\mathrm{Splay}$ angle & $11.8(9)[10.4(9)]$ & $15.9(9)[20.5(9)]$ \\
\hline Out of plane displacement & \\
\hline$S(1)$ & $0.092[0.152]$ & $0.099[0.018]$ \\
$\mathrm{S}(9)$ & $0.146[0.147]$ & $0.063[0.103]$ \\
\hline
\end{tabular}

[] denotes data from second molecule in asymmetric unit.

Table 3. Selected bond lengths $[\AA]$, angles $\left[^{\circ}\right]$ and displacements $[\AA]$ for $\mathbf{H}_{\mathbf{2}} \mathbf{C}$ and $\mathbf{H}_{\mathbf{2}} \mathbf{d}$

\begin{tabular}{llll}
\hline & $\mathbf{H}_{2} \mathbf{C}^{\mathrm{a}}$ & & $\mathbf{H}_{\mathbf{2}} \mathbf{d}$ \\
\hline $\mathrm{S}(1)-\mathrm{C}(1)$ & $1.764(8)-1.783(8)$ & $\mathrm{S}(1)-\mathrm{C}(1)$ & $1.776(4)[1.773(3)]$ \\
$\mathrm{S}(8)-\mathrm{C}(8)$ & $1.760(8)-1.785(8)$ & $\mathrm{S}(2)-\mathrm{C}(2)$ & $1.771(3)[1.777(4)]$ \\
$\mathrm{S}(1) \cdots \mathrm{S}(8)$ & $3.716-4.335(3)$ & $\mathrm{S}(1) \cdots \mathrm{S}(2)$ & $3.068(1)[3.072(1)]$ \\
$\mathrm{C}:(1)-(2)-(7)-(8)$ & $(-) 79.8-(-) 102.1(9)$ & $\mathrm{S}(1)-\mathrm{C}(1) \cdots \mathrm{C}(2)-\mathrm{S}(2)$ & $1.1(4)[2.3(4)]$ \\
& & Splay angle & $-3.4(4)[-3.5(4)]$ \\
\hline Out of plane displacement & & \\
\hline $\mathrm{S}(1)$ & $0.007-0.065$ & $\mathrm{~S}(1)$ & $0.025[0.041]$ \\
$\mathrm{S}(8)$ & $0.012-0.137$ & $\mathrm{~S}(2)$ & $0.030[0.036]$ \\
\hline
\end{tabular}

${ }^{\mathrm{a}}$ ranges quoted for molecules within the asymmetric unit.

[] denotes data from second molecule in asymmetric unit.

${ }^{b}$ calculated as $(S(1)-C(1)-C(2)+C(1)-C(2)-S(2))-240$. 
Although synthesis and spectral characterisation of complexes $\mathbf{1}$ and $\mathbf{2}$ were previously reported,[37] no x-ray crystal data was published. Crystals suitable for X-ray studies were obtained from diethylether by slow evaporation.
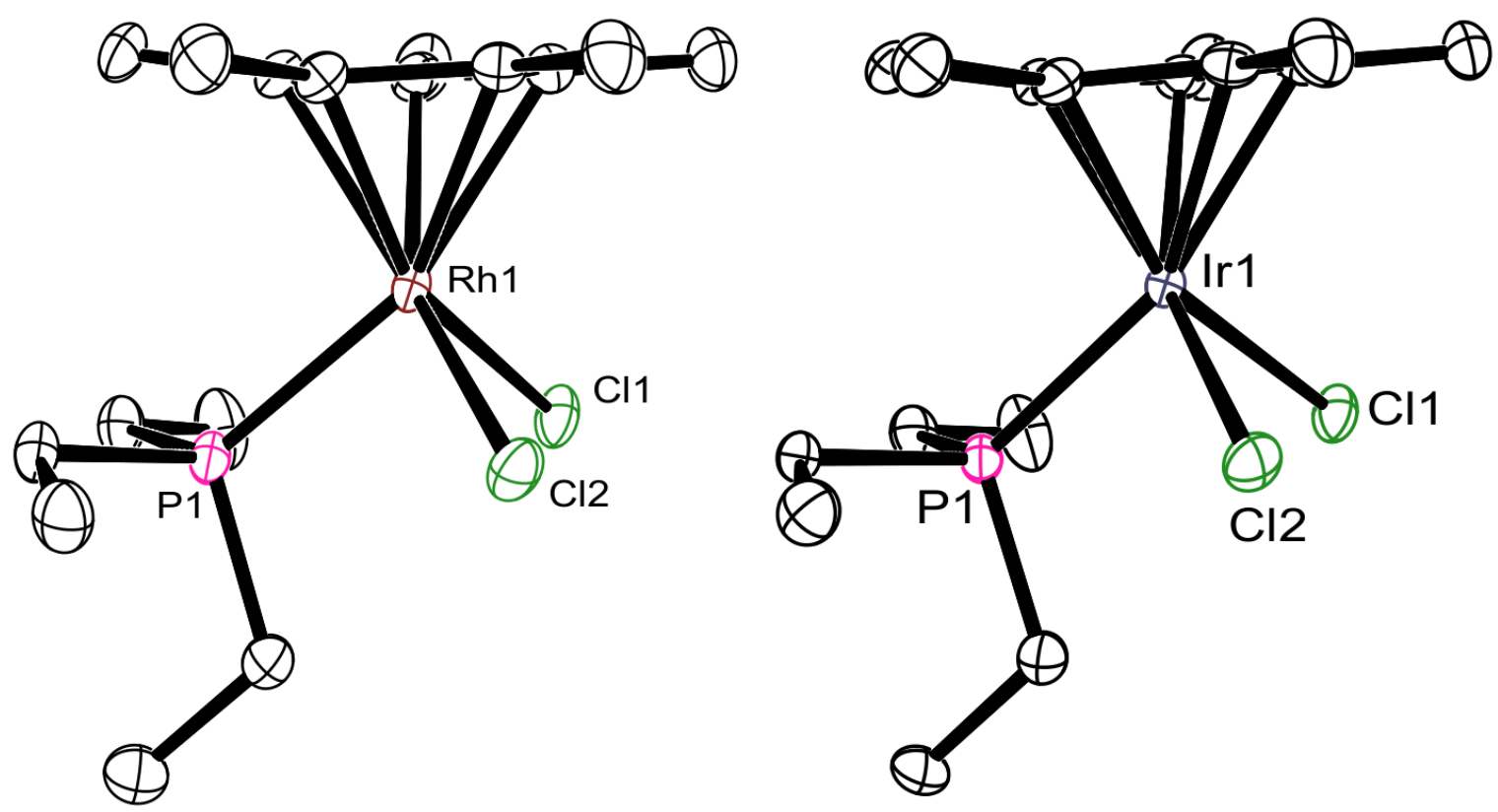

Figure 4. Displacement ellipsoid representation of (left to right) $\left[\mathrm{Cp}^{*} \mathrm{RhCl}_{2} \mathrm{PEt}_{3}\right] \cdot \mathrm{H}_{2} \mathrm{O}\left(\mathbf{1} \cdot \mathrm{H}_{2} \mathrm{O}\right)$ and $\left[\mathrm{Cp}^{*} \mid \mathrm{ICl}_{2} \mathrm{PEt}_{3}\right] \cdot \frac{1}{2} \mathrm{H}_{2} \mathrm{O}\left(2 \cdot 1 / 2 \mathrm{H}_{2} \mathrm{O}\right)$ showing the piano stool geometry. The water molecules and hydrogen atoms are omitted for clarity.

The X-ray diffraction of 1 and 2 (Figure 4, Table 4) shows that the complexes are isostructural, attaining piano stool geometry with a slightly tilted $\eta^{5}-\mathrm{Cp} *$ ring $(\mathrm{Rh}-\mathrm{C}$ bond lengths 2.155(3)-2.230(3) $\AA$; Ir-C 2.172(5)-2.255(5) $\AA$ ). The Cl-M-P angles are all close to the idealised $90^{\circ}$ whilst the $\mathrm{Rh}-\mathrm{Cl} / \mathrm{P}$ bond lengths are similar to other half sandwich complexes, ranging from 2.322-2.341 $\AA$ for the Rh-P bond and 2.392-2.413 $\AA$ for the Rh-Cl bond.[42, 43] The Ir-C/P bond lengths were also comparable to the literature, Ir-P; $2.284-2.318 \AA$, IrCl; 2.402-2.418 ̊̊.[44]

Table 4. Selected bond lengths $[\AA]$ and angles $\left[^{\circ}\right]$ for 1 \& 2

\begin{tabular}{lll}
\hline & $\mathbf{1}$ & $\mathbf{2}$ \\
\hline $\mathrm{M}(1)-\mathrm{Cl}(1)$ & $2.4124(8)$ & $2.425(1)$
\end{tabular}




\begin{tabular}{lll}
\hline $\mathrm{M}(1)-\mathrm{Cl}(2)$ & $2.4072(7)$ & $2.423(1)$ \\
$\mathrm{M}(1)-\mathrm{P}(1)$ & $2.3102(7)$ & $2.320(1)$ \\
$\mathrm{M}(1)-\mathrm{C}(1)$ & $2.155(3)$ & $2.182(5)$ \\
$\mathrm{M}(1)-\mathrm{C}(2)$ & $2.222(3)$ & $2.255(5)$ \\
$\mathrm{M}(1)-\mathrm{C}(3)$ & $2.230(3)$ & $2.255(5)$ \\
$\mathrm{M}(1)-\mathrm{C}(4)$ & $2.155(3)$ & $2.172(5)$ \\
$\mathrm{M}(1)-\mathrm{C}(5)$ & $2.175(3)$ & $2.177(5)$ \\
$\mathrm{Cl}(1)-\mathrm{M}(1)-\mathrm{Cl}(2)$ & $90.95(3)$ & $88.36(4)$ \\
$\mathrm{Cl}(1)-\mathrm{M}(1)-\mathrm{P}(1)$ & $89.63(3)$ & $89.41(4)$ \\
$\mathrm{Cl}(2)-\mathrm{M}(1)-\mathrm{P}(1)$ & $89.33(2)$ & $89.10(4)$ \\
\hline
\end{tabular}

\section{Rhodium Complexes 3a-c}

The solid state structures of $\mathbf{3 a - 3 c}$ are shown in Figure 5 and Figure 6 with selected structural parameters listed in Table 5. As with complexes $\mathbf{1}$ and $\mathbf{2}$, the rhodium centre adopts piano stool geometry. The Rh-S bonds lengthen going through the series, varying from 2.3371(9) and 2.3307(7) $\AA$ in 3a, 2.342(2) and 2.344(2) $\AA$ in 3 b to 2.3840(8) and 2.3821(9) $\AA$ in 3c. These are comparable to other half sandwich complexes with Rh-S bond lengths reported by Jin and co-workers ranging from 2.340-2.386 A..[45-47] The Rh-P bonds are slightly shortened in all the complexes, 3a 2.2914(8) $\AA$, 3b, 2.299(2) $\AA$, 3c 2.2939(8) $\AA$ compared to 1 . The Rh-P bond lengths are similar to those previously reported for half sandwich rhodium complexes with neutral phosphine ligands ranging from 2.274-2.295 $\AA$ A.[48] The distance between the two sulfur donor atoms increases through the series. Comparing the S...S distance between the free and bound ligands an increase is observed from 2.951(2) $\AA$ to 3.173(1) $\AA$ for $\mathbf{H}_{\mathbf{2}} \mathbf{a}$ and 3.1038(13) $\AA$ to 3.231(2) $\AA$ for $\mathbf{H}_{\mathbf{2}} \mathbf{b}$ as the rhodium centre bridges the peri positions. Complex $3 \mathrm{c}$ has the largest distance between the sulfur atoms $(3.448(1) \AA$ ) as they are attached to a much more flexible backbone. This represents a decrease compared to the pro-ligand as the sulfur atoms are held closer together within the coordination sphere. 


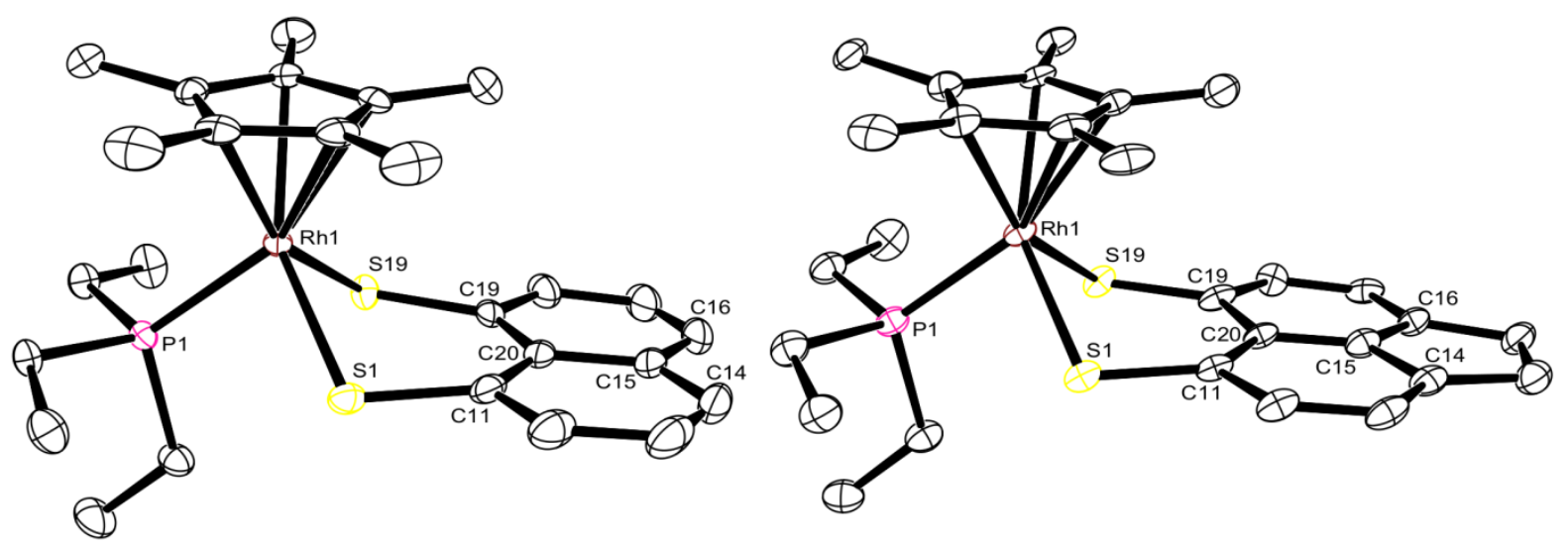

Figure 5. Displacement ellipsoid representation of (left to right) [Cp*Rh(NaphthS 2$\left.) \mathrm{PEt}_{3}\right]$ (3a) and $\left[\mathrm{Cp} * \mathrm{Rh}\left(\mathrm{AcenapS}_{2}\right) \mathrm{PEt}_{3}\right](\mathbf{3 b})$. The molecule of solvated $\mathrm{CH}_{2} \mathrm{Cl}_{2}$ has been omitted from $\mathbf{3 b}$ for clarity, hydrogen atoms are omitted from all structures for clarity.

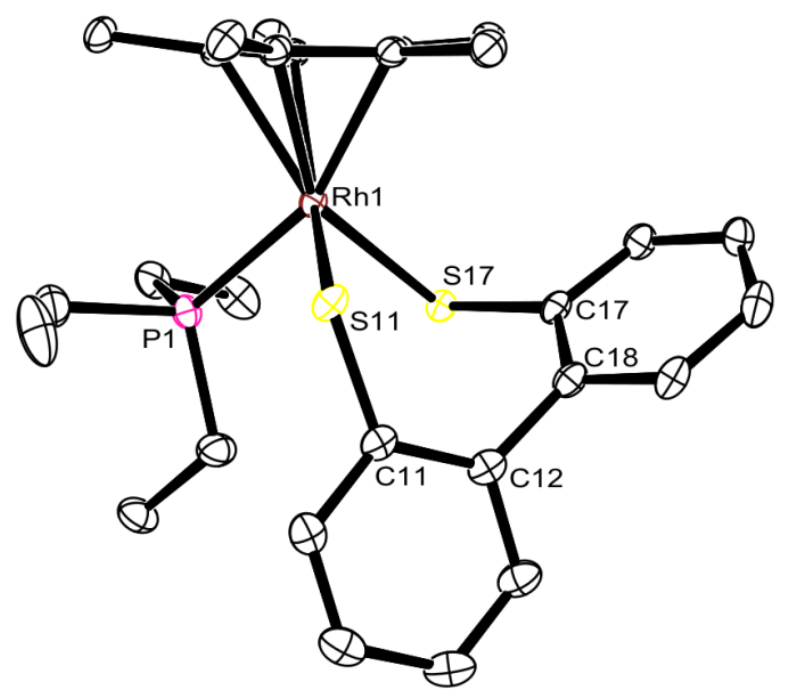

Figure 6. Displacement ellipsoid representation of $\left[\mathrm{Cp}^{*} \mathrm{Rh}\left(\mathrm{BiphenS}_{2}\right) \mathrm{PEt}_{3}\right]$ (3c). Hydrogen atoms are omitted for clarity.

All the non- $\mathrm{Cp}^{*}$ angles around the rhodium centre are slightly reduced to less than $90^{\circ}$ for complexes $3 \mathbf{a}-\mathbf{b}$. This can be explained by the rigid ligand backbone preventing the sulfur atoms from moving further apart to adopt a more relaxed geometry. The effect is most marked for the naphthalene system as the sulfur atoms in the peri-position are restricted to a slightly shorter distance than those in the acenaphthene system. The splay angles are almost identical at $19.7^{\circ}(3 \mathrm{a})$ and $20.5^{\circ}(\mathbf{3 b})$, respectively. Both of these values are increased compared to the pro-ligands as the rhodium metal pushes the sulfur atoms apart. The torsion angle $S(1)-C(11) \cdots C(19)-S(19)$ is slightly bigger in $\mathbf{3 a}$ than in $\mathbf{3 b}$, as is the 
out of plane displacement of the sulfur atoms from the backbone. Both complexes show comparable buckling of the central ring system with the central $\mathrm{C}-\mathrm{C}-\mathrm{C}-\mathrm{C}$ torsions ranging $176.7^{\circ}-178.9^{\circ}$

Complex $3 c$ shows a more relaxed dithiol ligand geometry, resulting in two of the angles around the rhodium being slightly above $90^{\circ}\left(92.69(3)^{\circ}, 93.16(3)^{\circ}\right)$. The ability of the backbone to twist along the central $\mathrm{C}-\mathrm{C}$ bond removes the restrictions on the sulfur atoms observed in $\mathbf{3 a}$ and $\mathbf{3 b}$. The torsion angle between the two aromatic rings is $-68.0(4)^{\circ}$, a smaller value than that observed in the pro-ligand. The out of plane displacement of the sulfur atoms is smaller than in the peri-backbone containing complexes.

Table 5. Selected bond lengths $[\AA]$, angles $\left[^{\circ}\right]$ and displacements $[\AA ̊]$ for 3a-c

\begin{tabular}{lllll}
\hline & $3 a$ & $3 b$ & & $3 c$ \\
\hline $\mathrm{Rh}(1)-\mathrm{S}(1)$ & $2.3371(9)$ & $2.342(2)$ & $\mathrm{Rh}(1)-\mathrm{S}(11)$ & $2.3840(8)$ \\
$\mathrm{Rh}(1)-\mathrm{S}(19)$ & $2.3307(7)$ & $2.344(2)$ & $\mathrm{Rh}(1)-\mathrm{S}(17)$ & $2.3821(9)$ \\
$\mathrm{Rh}(1)-\mathrm{P}(1)$ & $2.2914(8)$ & $2.299(2)$ & $\mathrm{Rh}(1)-\mathrm{P}(1)$ & $2.2939(8)$ \\
$\mathrm{S}(1)-\mathrm{C}(11)$ & $1.765(3)$ & $1.764(8)$ & $\mathrm{S}(11)-\mathrm{C}(11)$ & $1.772(3)$ \\
$\mathrm{S}(19)-\mathrm{C}(19)$ & $1.763(3)$ & $1.769(8)$ & $\mathrm{S}(17)-\mathrm{C}(17)$ & $1.790(3)$ \\
$\mathrm{S}(1) \cdots \mathrm{S}(19)$ & $3.173(1)$ & $3.231(2)$ & $\mathrm{S}(11) \cdots \mathrm{S}(17)$ & $3.448(1)$ \\
$\mathrm{S}(1)-\mathrm{Rh}(1)-\mathrm{S}(19)$ & $85.64(3)$ & $87.19(6)$ & $\mathrm{S}(11)-\mathrm{Rh}(1)-\mathrm{S}(17)$ & $92.69(3)$ \\
$\mathrm{S}(1)-\mathrm{Rh}(1)-\mathrm{P}(1)$ & $89.40(3)$ & $88.72(7)$ & $\mathrm{S}(11)-\mathrm{Rh}(1)-\mathrm{P}(1)$ & $93.16(3)$ \\
$\mathrm{S}(19)-\mathrm{Rh}(1)-\mathrm{P}(1)$ & $88.33(3)$ & $88.18(7)$ & $\mathrm{S}(17)-\mathrm{Rh}(1)-\mathrm{P}(1)$ & $89.60(3)$ \\
$\mathrm{Splay}$ angle & 19.7 & 20.5 & $\mathrm{C}:(11)-(12)-(18)-(17)$ & $-68.0(4)$ \\
$\mathrm{S}(1)-\mathrm{C}(11) \cdots \mathrm{C}(19)-\mathrm{S}(19)$ & $6.63(2)$ & $4.12(5)$ & & \\
$\mathrm{C}:(11)-(20)-(15)-(16)$ & $177.70(3)$ & $176.72(8)$ & & \\
$\mathrm{C}:(19)-(20)-(15)-(14)$ & $178.10(3)$ & $178.99(8)$ & & \\
\hline Out of plane displacement & & & & 0.114 \\
\hline $\mathrm{S}(1)$ & 0.211 & 0.181 & $\mathrm{~S}(11)$ & \\
$\mathrm{S}(19)$ & 0.067 & 0.028 & $\mathrm{~S}(17)$ & \\
\hline & & & & \\
\hline
\end{tabular}

Iridium Complexes $4 a-c$ 
The solid state structures of $\mathbf{4 a - c}$ are shown in Figure 7 and Figure 8 with selected structural parameters listed in Table 6. The lanthanide contraction results in the atomic radius of iridium being similar to that of rhodium, the complexes adopting similar structures to that of rhodium analogues. The drop in the observed tilt of the C $\mathrm{p}^{*}$ moiety is less in this series cf. the rhodium complexes. The Ir-S bond lengthens going from $4 a-4 c$ ranging from $2.339(1) \AA$ in $4 \mathrm{a}$ to 2.409 (9) $\AA$ in $4 \mathrm{c}$ and are comparable to other Ir-S bonds. [49] The Ir-P bond length increases going from $\mathbf{4 a}$ to $\mathbf{4 c}$ with all the complexes showing a shortened $\mathrm{Ir}-\mathrm{P}$ bond compared to the starting complex. The $S \cdots S$ distance increases across the series as before.
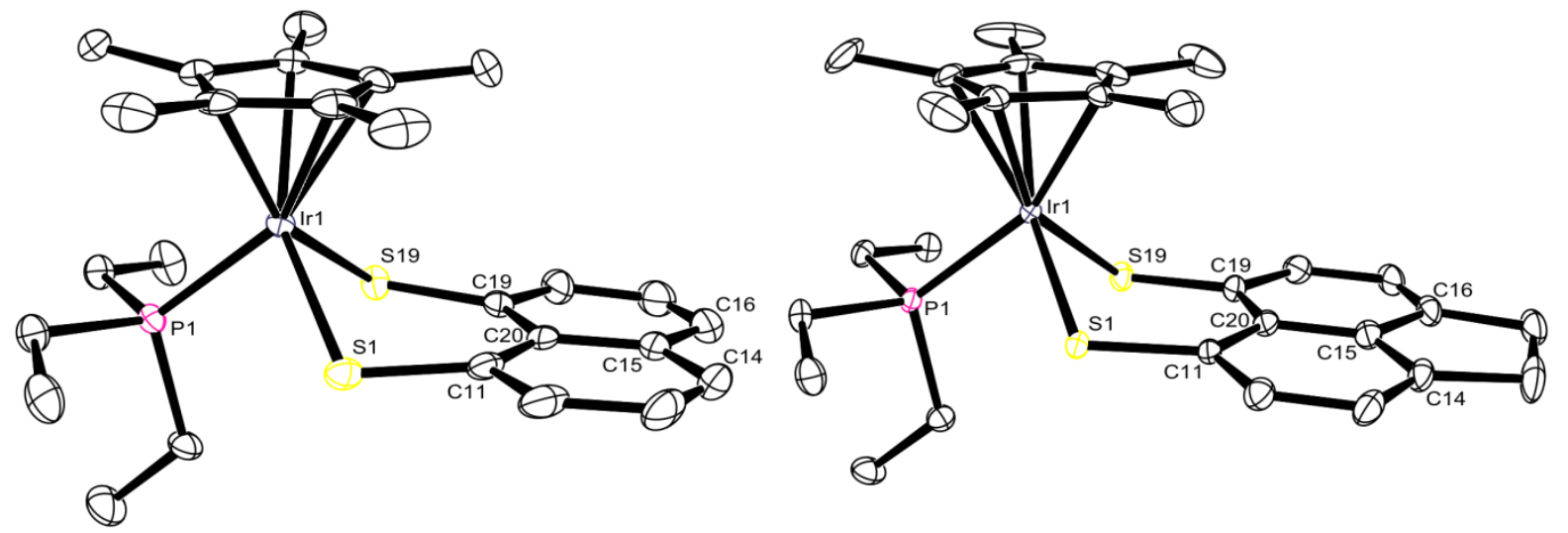

Figure 7. Displacement ellipsoid representation of (left to right) $\left[\mathrm{Cp} * \operatorname{Ir}\left(\mathrm{NaphthS}_{2}\right) \mathrm{PEt}_{3}\right](\mathbf{4 a})$, $\left[\mathrm{Cp}^{*} \operatorname{Ir}\left(\mathrm{AcenapS}_{2}\right) \mathrm{PEt}_{3}\right]$ (4b). Hydrogen atoms are omitted for clarity.

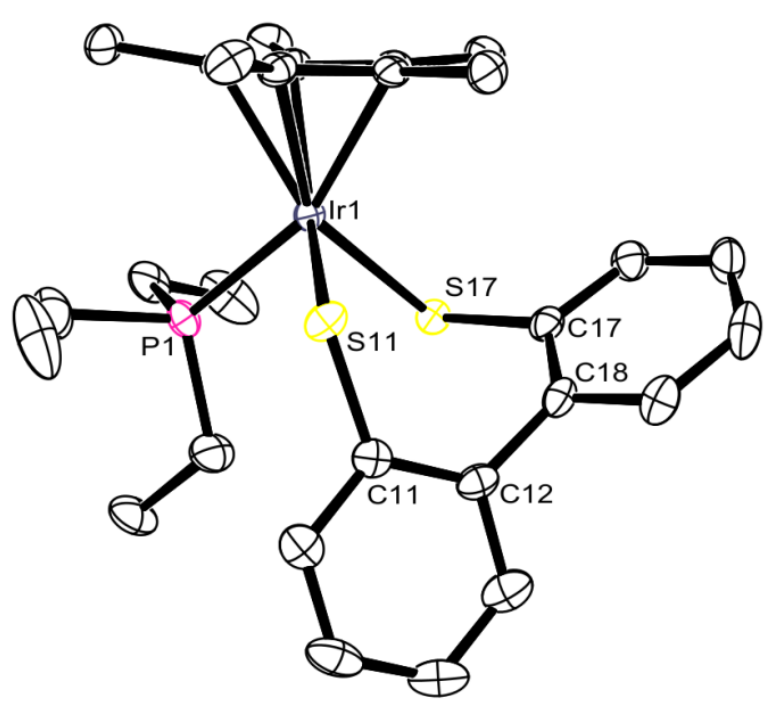

Figure 8. Displacement ellipsoid representation of $\left[C p^{*} \operatorname{Ir}\left(B^{2}\right.\right.$ iphenS $\left.\left._{2}\right) \mathrm{PEt}_{3}\right]$ (4c). Hydrogen atoms are omitted for clarity. 
The non- $\mathrm{Cp} *$ angles around the iridium centre for $\mathbf{4 a}$ and $\mathbf{4 b}$ are all less than $90^{\circ}$, with $\mathbf{4 c}$ having two greater than $90^{\circ}\left(92.08(3)^{\circ}, 92.64(3)^{\circ}\right)$. The $S \cdots S$ distance, splay angle and torsion $S(1)-C(11) \cdots C(19)-S(19)$ all increase in the iridium complexes compared to their rhodium analogues. The out of plane displacement of the sulfur atoms from the central ring systems are comparable to the rhodium analogues.

Table 6. Selected bond lengths $[\AA \AA]$, angles $\left[{ }^{\circ}\right]$ and displacements $[\AA ̊]$ for $\mathbf{4 a - c}$

\begin{tabular}{|c|c|c|c|c|}
\hline & $4 a$ & $4 b$ & & 4c \\
\hline $\operatorname{Ir}(1)-S(1)$ & $2.348(1)$ & $2.3509(9)$ & $\operatorname{Ir}(1)-S(11)$ & $2.409(1)$ \\
\hline $\operatorname{Ir}(1)-S(19)$ & $2.339(1)$ & $2.3579(9)$ & $\operatorname{Ir}(1)-S(17)$ & $2.4031(9)$ \\
\hline $\operatorname{Ir}(1)-P(1)$ & $2.276(1)$ & $2.2801(9)$ & $\operatorname{Ir}(1)-P(1)$ & $2.2993(9)$ \\
\hline$S(1)-C(11)$ & $1.763(5)$ & $1.775(3)$ & $S(11)-C(11)$ & $1.785(4)$ \\
\hline$S(19)-C(19)$ & $1.765(4)$ & $1.765(3)$ & $S(17)-C(17)$ & $1.801(3)$ \\
\hline$S(1) \cdots S(19)$ & $3.185(2)$ & $3.262(2)$ & $S(11) \cdots S(17)$ & $3.463(1)$ \\
\hline$S(1)-\operatorname{Ir}(1)-S(19)$ & $85.60(4)$ & $87.70(3)$ & $S(11)-\operatorname{Ir}(1)-S(17)$ & $92.08(3)$ \\
\hline$S(1)-\operatorname{Ir}(1)-P(1)$ & $89.38(4)$ & $88.87(3)$ & $S(11)-\operatorname{Ir}(1)-P(1)$ & $92.64(3)$ \\
\hline$S(19)-\operatorname{Ir}(1)-P(1)$ & $88.27(4)$ & $88.23(3)$ & $S(17)-\operatorname{Ir}(1)-P(1)$ & $89.45(3)$ \\
\hline Splay angle & 20.5 & 21.4 & C: (11)-(12)-(18)-(17) & $-66.83(5)$ \\
\hline$S(1)-C(11) \cdots C(19)-S(19)$ & $6.92(3)$ & $4.47(5)$ & & \\
\hline$C:(11)-(20)-(15)-(16)$ & $176.64(5)$ & $178.91(3)$ & & \\
\hline C: (19)-(20)-(15)-(14) & $179.60(5)$ & $177.41(3)$ & & \\
\hline \multicolumn{5}{|l|}{ Out of plane displacement } \\
\hline$S(1)$ & 0.195 & 0.073 & $S(11)$ & 0.124 \\
\hline$S(19)$ & 0.082 & 0.131 & $S(17)$ & 0.005 \\
\hline
\end{tabular}

\section{Conclusions}

We have prepared and fully characterised a series of new $\operatorname{Rh}(\mathrm{III})$ and $\operatorname{Ir}(\mathrm{III}) \eta^{5}-\mathrm{Cp}^{*}$ half sandwich complexes by ligand replacement reactions of $\left[\mathrm{Cp} * \mathrm{RhCl}_{2} \mathrm{PEt}_{3}\right]$ and $\left[\mathrm{Cp}^{*} \mid \mathrm{ICl}_{2} \mathrm{PEt}_{3}\right]$ with a series of dithiols attached to aromatic backbones. The nature of the backbone was varied to see the effect on the structure of the complex formed. The new complexes have been characterised by ${ }^{1} \mathrm{H},{ }^{13} \mathrm{C},{ }^{31} \mathrm{P}, \mathrm{IR}$ and Raman spectroscopy as well as elemental analysis 
and mass spectrometry. We have also fully characterised the ligand $\mathbf{H}_{\mathbf{2}} \mathbf{b}$ by ${ }^{1} \mathrm{H},{ }^{13} \mathrm{C}, \mathrm{IR}$ and Raman spectroscopy in addition to elemental analysis and mass spectrometry. The crystals structures of the ligands $\mathbf{H}_{\mathbf{2}} \mathbf{a}-\mathbf{H}_{\mathbf{2}} \mathbf{d}$ are also reported for completeness.

\section{Experimental}

\section{General}

Unless otherwise stated all manipulations were performed under an oxygen-free nitrogen atmosphere using standard schlenk techniques and glassware. Solvents were collected from an MBraun Solvent Purification System or dried and stored according to common procedures.[50] $\left[\mathrm{Cp}^{*} \mathrm{RhCl}_{2} \mathrm{PEt}_{3}\right]$ and $\left[\mathrm{Cp}^{*} \mid \mathrm{ICl}_{2} \mathrm{PEt} \mathrm{C}_{3}\right]$ were prepared following a procedure similar to that of Maitlis et al and are described below.[38] The disulfide precursors were made according to literature methods.[31-33] [Naphth $\left.(\mathrm{SH})_{2}\right], \quad\left[\mathrm{Acenap}(\mathrm{SH})_{2}\right]$ and [Biphen $(\mathrm{SH})_{2}$ ] were prepared following a modified literature procedure.[34] Benzene-1,2dithiol was prepared according to literature. $[35,36]$ The synthesis of $\left[\right.$ Acenap $\left.(\mathrm{SH})_{2}\right]$ is described below. IR and Raman spectra were collected on a Perkin Elmer 2000 NIR/Raman Fourier Transform spectrometer with a dipole pumped NdYAG near-IR excitation laser. ${ }^{1} \mathrm{H}$ and ${ }^{13} \mathrm{C}\left\{{ }^{1} \mathrm{H}\right\}$ NMR spectra were obtained on either a Bruker Avance 300 or a Bruker Avance III 500 spectrometer with $\delta_{\mathrm{H}} \& \delta_{\mathrm{C}}$ relative to TMS or residual solvent peaks $\left(\mathrm{CDCl}_{3} \delta_{\mathrm{H}} 7.26, \delta_{\mathrm{C}}\right.$ $77.2 \mathrm{ppm}) .{ }^{31} \mathrm{P}$ NMR spectra were performed on a Bruker Avance 300 spectrometer with $\delta_{\mathrm{P}}$ relative to external $85 \% \mathrm{H}_{3} \mathrm{PO}_{4}$. All measurements were performed at $25{ }^{\circ} \mathrm{C}$ with shifts reported in ppm. Electrospray $\left(\mathrm{ES}^{+/-}\right)$mass spectra were carried out by the University of St Andrews Mass Spectrometry Service and Atmospheric Pressure Chemical Ionisation ( $\left.\mathrm{APCl}^{+}\right)$ by the EPSRC National Mass Spectrometry Service, Swansea. Elemental analyses were performed by Stephen Boyer at the London Metropolitan University.

[Cp*RhCl $\left.{ }_{2} \mathrm{PEt}_{3}\right]$ (1). [Cp*RhCl$]_{2}(750 \mathrm{mg}, 1.21 \mathrm{mmol})$ was added to THF (30 mL) followed by $\mathrm{PEt}_{3}\left(318 \mathrm{mg}, 2.7 \mathrm{~mL}, 2.66 \mathrm{mmol} 1 \mathrm{M} \mathrm{sol}^{\mathrm{n}} \mathrm{THF}\right.$ ) and the suspension refluxed for $2 \mathrm{hrs}$. During this time the solid dissolved to leave a red solution which was cooled and the solvent removed under vacuum. Drying under vacuum for $4 \mathrm{hrs}$ removed excess ligand to afford the product as a red solid (1.03 g, $2.40 \mathrm{mmol}$, >99\%). Crystals suitable for X-ray work were obtained from ether. Anal. calcd. for $\mathrm{C}_{16} \mathrm{H}_{30} \mathrm{Cl}_{2} \mathrm{PRh}\left(426.05 \mathrm{~g} \mathrm{~mol}^{-1}\right.$ ): $\mathrm{C}, 44.98 ; \mathrm{H}, 7.07$. Found: 
C, 44.89; $\mathrm{H}, 7.20 .{ }^{1} \mathrm{H}$ NMR $\left(500 \mathrm{MHz}, \mathrm{CDCl}_{3}\right): \delta=2.11-2.03\left(\mathrm{~m}, 6 \mathrm{H}, \mathrm{PCH}_{2} \mathrm{CH}_{3}\right), 1.66\left(\mathrm{~d},{ }^{4} J_{\mathrm{HP}}=\right.$ $\left.3.1 \mathrm{~Hz}, 15 \mathrm{H}, \mathrm{Cp}-\mathrm{CH}_{3}\right), 1.15\left(\mathrm{dt},{ }^{3} J_{\mathrm{HP}}=15.3 \mathrm{~Hz},{ }^{3} \mathrm{~J}_{\mathrm{HH}}=7.8 \mathrm{~Hz}, 9 \mathrm{H}, \mathrm{PCH}_{2} \mathrm{CH}_{3}\right) .{ }^{13} \mathrm{C}\left\{{ }^{1} \mathrm{H}\right\} \mathrm{NMR}(125$ $\left.\mathrm{MHz}, \mathrm{CDCl}_{3}\right) \delta=98.0\left(\mathrm{dd},{ }^{1} J_{\mathrm{CRh}}=7.5 \mathrm{~Hz},{ }^{2} J_{\mathrm{CP}}=2.8 \mathrm{~Hz}, \mathrm{C}_{\mathrm{q}}, \mathrm{Cp} * \mathrm{C}\right), 16.8\left(\mathrm{~d},{ }^{1} J_{\mathrm{CP}}=27.3 \mathrm{~Hz}\right.$, $\left.\mathrm{PCH}_{2} \mathrm{CH}_{3}\right), 9.3\left(\mathrm{Cp}_{-} \mathrm{CH}_{3}\right), 8.0\left(\mathrm{~d},{ }^{2} \mathrm{~J}_{\mathrm{CP}}=4.6 \mathrm{~Hz}, \mathrm{PCH}_{2} \mathrm{CH}_{3}\right) .{ }^{31} \mathrm{P}\left\{{ }^{1} \mathrm{H}\right\}\left(121 \mathrm{MHz}, \mathrm{CDCl}_{3}\right): \delta=28.17$ (d, $\left.{ }^{1} J_{\mathrm{PRh}}=137.5 \mathrm{~Hz}\right) . \mathrm{MS}\left(\mathrm{ES}^{+}\right): \mathrm{m} / z(\%) 391.08(100)[\mathrm{M}-\mathrm{Cl}]^{+}$. HRMS $\left(\mathrm{ES}^{+}\right)[\mathrm{M}-\mathrm{Cl}]^{+} \mathrm{C}_{16} \mathrm{H}_{30} \mathrm{ClPRh}$ requires 391.0828 , found 391.0813 .

[Cp* $\left.\mathrm{IrCl}_{2} \mathrm{PEt}_{3}\right]$ (2). This was prepared as per complex 1 using $\left[\mathrm{Cp} * \mid \mathrm{ICl}_{2}\right]_{2}$ (750 $\left.\mathrm{mg}, 0.94 \mathrm{mmol}\right)$ and $\mathrm{PEt}_{3}$ (245 mg, $2.1 \mathrm{~mL}, 2.07 \mathrm{mmol}, 1 \mathrm{M}$ sol ${ }^{\mathrm{n}} \mathrm{THF}$ ) giving 2 as a yellow solid (968 mg, 1.87 mmol, >99\%). Crystals suitable for X-ray work were obtained from ether. Anal. calcd. for $\mathrm{C}_{16} \mathrm{H}_{30} \mathrm{Cl}_{2} \operatorname{IrP}\left(516.11 \mathrm{~g} \mathrm{~mol}^{-1}\right): \mathrm{C}, 37.20 ; \mathrm{H}, 5.85$. Found: C, 37.09; $\mathrm{H}, 5.99 .{ }^{1} \mathrm{H}$ NMR $(500 \mathrm{MHz}$, $\left.\mathrm{CDCl}_{3}\right): \delta=2.14-2.06\left(\mathrm{~m}, 6 \mathrm{H}, \mathrm{PCH}_{2} \mathrm{CH}_{3}\right), 1.67\left(\mathrm{~d},{ }^{4} J_{\mathrm{HP}}=1.7 \mathrm{~Hz}, 15 \mathrm{H}, \mathrm{Cp}-\mathrm{CH}_{3}\right), 1.11\left(\mathrm{dt},{ }^{3} J_{\mathrm{HP}}=\right.$ $\left.15.5 \mathrm{~Hz},{ }^{3} J_{\mathrm{HH}}=7.7 \mathrm{~Hz}, 9 \mathrm{H}, \mathrm{PCH}_{2} \mathrm{CH}_{3}\right) .{ }^{13} \mathrm{C}\left\{{ }^{1} \mathrm{H}\right\} \mathrm{NMR}\left(125 \mathrm{MHz}, \mathrm{CDCl}_{3}\right): \delta=91.2\left(\mathrm{~d},{ }^{2} \mathrm{JPP}_{\mathrm{CP}}=2.6\right.$ $\left.\mathrm{Hz}, \mathrm{C}_{\mathrm{q}}, \mathrm{Cp} * \mathrm{C}\right), 16.1\left(\mathrm{~d},{ }^{1} \mathrm{~J}_{\mathrm{CP}}=36.1 \mathrm{~Hz}, \mathrm{PCH}_{2} \mathrm{CH}_{3}\right), 8.9\left(\mathrm{Cp}-\mathrm{CH}_{3}\right), 7.5\left(\mathrm{~d},{ }^{2} \mathrm{JP}_{\mathrm{CP}}=3.96 \mathrm{~Hz}, \mathrm{PCH}_{2} \mathrm{CH}_{3}\right)$. ${ }^{31} \mathrm{P}\left\{{ }^{1} \mathrm{H}\right\}\left(121 \mathrm{MHz}, \mathrm{CDCl}_{3}\right): \delta=-5.78$ (s). MS $\left(\mathrm{ES}^{+}\right): m / z$ (\%) $481.13(100)[\mathrm{M}-\mathrm{Cl}]^{+}$. HRMS $\left(\mathrm{ES}^{+}\right)$ $[\mathrm{M}-\mathrm{Cl}]^{+} \mathrm{C}_{16} \mathrm{H}_{30} \mathrm{Cll} \mathrm{rP}$ requires 481.1402, found 481.1376 .

[Acenap $\left.(\mathrm{SH})_{2}\right]\left(\mathbf{H}_{\mathbf{2}}\right.$ b). A solution of $\left[\right.$ Acenaps $\left._{2}\right](100 \mathrm{mg}, 0.46 \mathrm{mmol})$ in THF $(30 \mathrm{~mL})$ was added dropwise to an ethanol $(10 \mathrm{~mL})$ suspension of $\mathrm{NaBH}_{4}(80 \mathrm{mg}, 2.11 \mathrm{mmol})$ at $0{ }^{\circ} \mathrm{C}$. Upon complete addition the reaction was stirred for 15 mins at this temperature then water $(30 \mathrm{~mL})$ added. The solution was acidified using $3 \mathrm{M} \mathrm{HCl}$ then extracted with ether $(3 \times 30$ $\mathrm{mL}$ ) and the combined organic layers dried over magnesium sulfate. Removal of the solvent under vacuum yielded a very pale brown solid (98 $\mathrm{mg}, 0.45 \mathrm{mmol}, 97 \%$ ). Crystals suitable for X-ray work were obtained from recrystallising in boiling hexane. Anal. calcd. for $\mathrm{C}_{12} \mathrm{H}_{10} \mathrm{~S}_{2}$

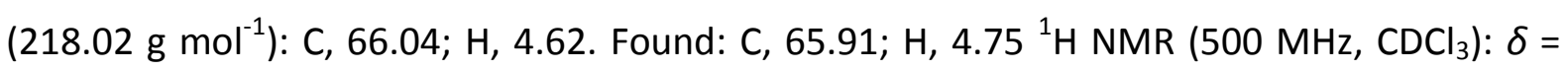
$7.47\left(\mathrm{~d},{ }^{3} \mathrm{~J}_{\mathrm{HH}}=7.2 \mathrm{~Hz}, 2 \mathrm{H}, \operatorname{Ar}-H\right), 7.09\left(\mathrm{~d},{ }^{3} \mathrm{~J}_{\mathrm{HH}}=7.2 \mathrm{~Hz}, 2 \mathrm{H}, \mathrm{Ar}-H\right), 4.16(\mathrm{~s}, 2 \mathrm{H}, 2 \times \mathrm{S}-H), 3.31$ $\left(\mathrm{s}, 4 \mathrm{H}, \mathrm{CH}_{2} \mathrm{CH}_{2}\right) \cdot{ }^{13} \mathrm{C}\left\{{ }^{1} \mathrm{H}\right\}$ NMR $\left(125 \mathrm{MHz}, \mathrm{CDCl}_{3}\right): \delta=145.8\left(\mathrm{C}_{\mathrm{q}}, \mathrm{Ar}-\mathrm{C}\right), 141.3\left(\mathrm{C}_{\mathrm{q}}, \mathrm{Ar}-\mathrm{C}\right), 133.4$ $(\mathrm{CH}, \operatorname{Ar}-\mathrm{C}), 130.4\left(\mathrm{C}_{\mathrm{q}}, \mathrm{Ar}-\mathrm{C}\right), 123.2\left(\mathrm{C}_{\mathrm{q}}, \mathrm{Ar}-\mathrm{C}\right), 120.1$ ( $\left.\mathrm{CH}, \mathrm{Ar}-\mathrm{C}\right), 30.0\left(\mathrm{CH}_{2} \mathrm{CH}_{2}\right)$. IR (KBr): $v_{\max } / \mathrm{cm}^{-1} 2921 \mathrm{w}\left(\mathrm{v}_{\mathrm{C}-\mathrm{H}}\right), 2510 \mathrm{w}\left(\mathrm{v}_{\mathrm{s}-\mathrm{H}}\right), 1459 \mathrm{~s}, 1197 \mathrm{~m}, 833 \mathrm{~s}, 810 \mathrm{~m}$. Raman (glass capillary): $v_{\max } / \mathrm{cm}^{-1} 3059 \mathrm{~m}\left(\mathrm{v}_{\mathrm{Ar}-H}\right), 2931 \mathrm{~m},\left(v_{\mathrm{C}-H}\right), 2546 \mathrm{~s}\left(\mathrm{v}_{\mathrm{S}-H}\right), 2514 \mathrm{~s}\left(\mathrm{v}_{\mathrm{S}-H}\right), 1599 \mathrm{~s}, 1566 \mathrm{~s}, 1440 \mathrm{~s}, 1412 \mathrm{~s}$, 1336s, 580s $\left(v_{\mathrm{C}-\mathrm{S}}\right)$. MS $\left(\mathrm{ES}^{-}\right): \mathrm{m} / z(\%) 217.01(100)[\mathrm{M}-\mathrm{H}]^{-}$. 
[Cp*Rh(NaphthS S $_{2}$ PEt 3 ] (3a). A THF (30 mL) solution containing [Cp*RhCl PEt $_{3}$ ] (150 mg, 0.35 mmol) and [Naphth $\left.(\mathrm{SH})_{2}\right](108 \mathrm{mg}, 0.56 \mathrm{mmol})$ was refluxed for $3 \mathrm{hrs}$. The solution was cooled and the solvent removed to afford the crude product as a red/orange solid. Purification by flash column chromatography (silica gel/ $\mathrm{CH}_{2} \mathrm{Cl}_{2}$ ) yielded the title compound as a red solid (157 mg, $0.28 \mathrm{mmol}, 82 \%)$. Crystals suitable for X-ray work were obtained from $\mathrm{CH}_{2} \mathrm{Cl}_{2}$. Anal. calcd. for $\mathrm{C}_{26} \mathrm{H}_{36} \mathrm{PRhS}_{2}\left(546.10 \mathrm{~g} \mathrm{~mol}^{-1}\right.$ ): $\mathrm{C}, 57.13 ; \mathrm{H}, 6.64$. Found: $\mathrm{C}, 56.94$; $\mathrm{H}, 6.67 .{ }^{1} \mathrm{H}$ NMR $\left(300 \mathrm{MHz}, \mathrm{CDCl}_{3}\right): \delta=7.86\left(\mathrm{dd},{ }^{3} \mathrm{~J}_{\mathrm{HH}}=7.3 \mathrm{~Hz},{ }^{4} J_{\mathrm{HH}}=1.2 \mathrm{~Hz}, 2 \mathrm{H}, \mathrm{Ar}-\mathrm{H}\right), 7.43$ $\left(\mathrm{dd},{ }^{3} J_{\mathrm{HH}}=8.0 \mathrm{~Hz},{ }^{4} J_{\mathrm{HH}}=1.2 \mathrm{~Hz}, 2 \mathrm{H}, \mathrm{Ar}-\mathrm{H}\right), 7.09\left(\mathrm{dd},{ }^{3} J_{\mathrm{HH}}=8.0,7.3 \mathrm{~Hz}, 2 \mathrm{H}, \mathrm{Ar}-\mathrm{H}\right), 2.08-1.95$ $\left(\mathrm{m}, 6 \mathrm{H}, \mathrm{PCH}_{2} \mathrm{CH}_{3}\right), 1.45\left(\mathrm{~d},{ }^{4} J_{\mathrm{HP}}=2.7 \mathrm{~Hz}, 15 \mathrm{H}, \mathrm{Cp}-\mathrm{CH}_{3}\right), 1.06\left(\mathrm{dt},{ }^{3} J_{\mathrm{HP}}=15.8 \mathrm{~Hz},{ }^{3} J_{\mathrm{HH}}=7.8 \mathrm{~Hz}\right.$, $\left.9 \mathrm{H}, \mathrm{PCH}_{2} \mathrm{CH}_{3}\right) \cdot{ }^{13} \mathrm{C}\left\{{ }^{1} \mathrm{H}\right\} \mathrm{NMR}\left(125 \mathrm{MHZ}, \mathrm{CDCl}_{3}\right): \delta=139.7\left(\mathrm{C}_{\mathrm{q}}, \mathrm{Ar}-\mathrm{C}\right), 136.2\left(\mathrm{C}_{\mathrm{q}}, \mathrm{Ar}-\mathrm{C}\right), 134.1$ $\left(\mathrm{C}_{q}, \operatorname{Ar}-\mathrm{C}\right), 128.2(\mathrm{CH}, \mathrm{Ar}-\mathrm{C}), 124.7(\mathrm{CH}, \mathrm{Ar}-\mathrm{C}), 123.6(\mathrm{CH}, \mathrm{Ar}-\mathrm{C}), 99.6\left(\mathrm{~m}, \mathrm{C}_{\mathrm{q}}, \mathrm{Cp} * \mathrm{C}\right), 15.9\left(\mathrm{~d},{ }^{1} \mathrm{~J}_{\mathrm{CP}}\right.$ $\left.=28.1, \mathrm{PCH}_{2} \mathrm{CH}_{3}\right), 8.7\left(\mathrm{Cp}-\mathrm{CH}_{3}\right), 7.4\left(\mathrm{~d},{ }^{2} \mathrm{~J}_{\mathrm{CP}}=2.9 \mathrm{~Hz}, \mathrm{PCH}_{2} \mathrm{CH}_{3}\right) .{ }^{31} \mathrm{P}\left\{{ }^{1} \mathrm{H}\right\} \mathrm{NMR}\left(121 \mathrm{MHz}, \mathrm{CDCl}_{3}\right)$ : $\delta=24.63\left(\mathrm{~d},{ }^{1} J_{\mathrm{PRh}}=146.7 \mathrm{~Hz}\right) . \mathrm{IR}(\mathrm{KBr}): \mathrm{v}_{\max } / \mathrm{cm}^{-1} 3034 \mathrm{w}\left(\mathrm{v}_{\mathrm{Ar}-\mathrm{H}}\right), 2931 \mathrm{~m}\left(\mathrm{v}_{\mathrm{C}-\mathrm{H}}\right), 1534 \mathrm{~s}, 1192 \mathrm{~m}$, $1034 m, 883 m, 759 s, 722 m$ ( $\left.v_{\text {P-C }}\right)$. Raman (glass capillary): $v_{\max } / \mathrm{cm}^{-1} 3037 \mathrm{w}\left(\mathrm{v}_{\mathrm{Ar}-\mathrm{H}}\right), 2912 \mathrm{~m}\left(\mathrm{v}_{\mathrm{C}-}\right.$ H), 1537s, 1314s, 884s, 594w (vc-s), 439s. MS (ES $): m / z(\%) 547.11$ (10) $[\mathrm{M}+\mathrm{H}]^{+}, 459.03$ (100) [M-PEt $3+\mathrm{OMe}], 428.01(50)\left[\mathrm{M}-\mathrm{PEt}_{3}\right]$.

[Cp*Rh(AcenapS $\left.\mathbf{C}_{2}\right) \mathbf{P E t}_{\mathbf{3}}$ (3b). This was prepared as per complex 3a using $\left[\mathrm{Cp} * \mathrm{RhCl}_{2} \mathrm{PEt}_{3}\right]$ (150 $\mathrm{mg}, 0.35 \mathrm{mmol})$ and $\left[\right.$ Acenap $\left.(\mathrm{SH})_{2}\right](122 \mathrm{mg}, 0.56 \mathrm{mmol})$ with refluxing for $5 \mathrm{hrs}$. 3b was obtained as a red solid (166 mg, $0.29 \mathrm{mmol}, 83 \%)$. Crystals suitable for X-ray work were obtained from $\mathrm{CH}_{2} \mathrm{Cl}_{2}$. Anal. calcd. for $\mathrm{C}_{28} \mathrm{H}_{38} \mathrm{PRhS}_{2}\left(572.12 \mathrm{~g} \mathrm{~mol}^{-1}\right.$ ): $\mathrm{C}, 58.72 ; \mathrm{H}, 6.70$. Found: C, 58.71; $\mathrm{H}, 6.92 .{ }^{1} \mathrm{H}$ NMR $(300 \mathrm{MHz}, \mathrm{CDCl}): \delta=7.76\left(\mathrm{~d},{ }^{3} \mathrm{~J}_{\mathrm{HH}}=6.9 \mathrm{~Hz}, 2 \mathrm{H}, \mathrm{Ar}-\mathrm{H}\right), 6.87\left(\mathrm{~d},{ }^{3} \mathrm{~J}_{\mathrm{HH}}\right.$ $=6.9 \mathrm{~Hz}, 2 \mathrm{H}, \mathrm{Ar}-\mathrm{H}), 3.13\left(\mathrm{~s}, 4 \mathrm{H}, \mathrm{CH}_{2} \mathrm{CH}_{2}\right), 2.09-1.96\left(\mathrm{~m}, 6 \mathrm{H}, \mathrm{PCH}_{2} \mathrm{CH}_{3}\right), 1.45\left(\mathrm{~d},{ }^{4} J_{\mathrm{HP}}=2.7 \mathrm{~Hz}\right.$, $\left.15 \mathrm{H}, \mathrm{Cp}-\mathrm{CH}_{3}\right), 1.08\left(\mathrm{dt},{ }^{3} J_{\mathrm{HP}}=15.4 \mathrm{~Hz},{ }^{3} J_{\mathrm{HH}}=7.6 \mathrm{~Hz}, 9 \mathrm{H}, \mathrm{PCH}_{2} \mathrm{CH}_{3}\right) .{ }^{13} \mathrm{C}\left\{{ }^{1} \mathrm{H}\right\} \mathrm{NMR}(125 \mathrm{MHz}$, $\left.\mathrm{CDCl}_{3}\right): \delta=141.5\left(\mathrm{C}_{\mathrm{q}}, \mathrm{Ar}-\mathrm{C}\right), 141.0\left(\mathrm{C}_{\mathrm{q}}, \mathrm{Ar}-\mathrm{C}\right), 135.0\left(\mathrm{C}_{\mathrm{q}}, \mathrm{Ar}-\mathrm{C}\right), 132.4\left(\mathrm{C}_{\mathrm{q}}, \mathrm{Ar}-\mathrm{C}\right), 128.7$ (CH, ArC), $117.7(\mathrm{CH}, \mathrm{Ar}-\mathrm{C}), 99.4\left(\mathrm{~m}, \mathrm{C}, \mathrm{Cp}{ }^{*} \mathrm{C}\right), 30.0\left(\mathrm{CH}_{2} \mathrm{CH}_{2}\right), 16.14\left(\mathrm{~d},{ }^{1} \mathrm{~J}_{\mathrm{CP}}=28.2 \mathrm{~Hz}, \mathrm{PCH}_{2} \mathrm{CH}_{3}\right), 8.8$ $\left(\mathrm{Cp}-\mathrm{CH}_{3}\right), 7.5\left(\mathrm{~d},{ }^{2} \mathrm{~J}_{\mathrm{CP}}=2.9 \mathrm{~Hz}, \mathrm{PCH}_{2} \mathrm{CH}_{3}\right) \cdot{ }^{31} \mathrm{P}\left\{{ }^{1} \mathrm{H}\right\} \mathrm{NMR}\left(121 \mathrm{MHz}, \mathrm{CDCl}_{3}\right): \delta=24.95\left(\mathrm{~d},{ }^{1} J_{\mathrm{PRh}}=\right.$ $145.9 \mathrm{~Hz})$. IR ( $\mathrm{KBr}): v_{\max } / \mathrm{cm}^{-1} 2928 \mathrm{~s}\left(\mathrm{v}_{\mathrm{C}-\mathrm{H}}\right), 1406 \mathrm{~s}, 1229 \mathrm{~m}, 1104 \mathrm{~m}, 1033 \mathrm{~s}, 831 \mathrm{~m}, 758 \mathrm{~s}, 721 \mathrm{~s}$ $\left(v_{\text {C-P }}\right)$. Raman (glass capillary): $v_{\max } / \mathrm{cm}^{-1} 2910 \mathrm{~m}\left(\mathrm{v}_{\mathrm{C}-\mathrm{H}}\right), 1595 \mathrm{~s}, 1557 \mathrm{~m}, 1406 \mathrm{~s}, 1323 \mathrm{~s}, 1032 \mathrm{~m}$, $827 \mathrm{~m}, 727 \mathrm{~s}\left(\mathrm{v}_{\mathrm{C}-\mathrm{P}}\right), 579 \mathrm{~m}\left(\mathrm{v}_{\mathrm{C}-\mathrm{S}}\right) . \mathrm{MS}\left(\mathrm{ES}^{+}\right): \mathrm{m} / \mathrm{z}(\%) 573.13(35)[\mathrm{M}+\mathrm{H}]^{+}, 454.03$ (100) [M-PEt $\left.{ }_{3}\right]$. 
[Cp*Rh(BiphenS $\left.\left.\mathbf{S}_{2}\right) \mathrm{PEt}_{3}\right]$ (3c). This was prepared as per complex 3a using $\left[\mathrm{Cp}^{*} \mathrm{RhCl}_{2} \mathrm{PEt}_{3}\right]$ (150 $\mathrm{mg}, 0.35 \mathrm{mmol})$ and [Biphen $\left.(\mathrm{SH})_{2}\right](122 \mathrm{mg}, 0.56 \mathrm{mmol})$ with refluxing for $5 \mathrm{hrs}$. 3c was obtained as a dark purple solid (160 mg, $0.27 \mathrm{mmol}, 80 \%)$. Crystals suitable for X-ray work were obtained from $\mathrm{CH}_{2} \mathrm{Cl}_{2}$. Anal. calcd. for $\mathrm{C}_{28} \mathrm{H}_{38} \mathrm{PRhS}_{2}\left(572.12 \mathrm{~g} \mathrm{~mol}^{-1}\right)$ : $\mathrm{C}, 58.72 ; \mathrm{H}, 6.69$. Found: $\mathrm{C}, 58.69 ; \mathrm{H}, 6.74 .{ }^{1} \mathrm{H}$ NMR $\left(300 \mathrm{MHz}, \mathrm{CDCl}_{3}\right): \delta=7.69-7.61(\mathrm{~m}, 2 \mathrm{H}, \mathrm{Ar}-\mathrm{H}), 7.19-7.12$ $(\mathrm{m}, 2 \mathrm{H}, \mathrm{Ar}-\mathrm{H}), 7.01-6.92(\mathrm{~m}, 2 \mathrm{H}, \mathrm{Ar}-\mathrm{H}), 6.69\left(\mathrm{dd},{ }^{3} \mathrm{~J}_{\mathrm{HH}}=7.5 \mathrm{~Hz},{ }^{4} J_{\mathrm{HH}}=1.6 \mathrm{~Hz}, 1 \mathrm{H}, \mathrm{Ar}-\mathrm{H}\right), 6.68$ $\left(\mathrm{dd},{ }^{3} J_{\mathrm{HH}}=7.5 \mathrm{~Hz},{ }^{4} J_{\mathrm{HH}}=1.6 \mathrm{~Hz}, 1 \mathrm{H}, \mathrm{Ar}-\mathrm{H}\right), 2.04-1.86\left(\mathrm{~m}, 3 \mathrm{H}, \mathrm{PCH}_{2} \mathrm{CH}_{3}\right), 1.73-1.58(\mathrm{~m}, 3 \mathrm{H}$, $\left.\mathrm{PCH}_{2} \mathrm{CH}_{3}\right), 1.52\left(\mathrm{~d},{ }^{4} J_{\mathrm{HP}}=2.9 \mathrm{~Hz}, 15 \mathrm{H}, \mathrm{Cp}-\mathrm{CH}_{3}\right), 1.04\left(\mathrm{dt},{ }^{3} J_{\mathrm{HP}}=15.0 \mathrm{~Hz},{ }^{3} J_{\mathrm{HH}}=7.6 \mathrm{~Hz}, 9 \mathrm{H}\right.$, $\left.\mathrm{PCH}_{2} \mathrm{CH}_{3}\right) .{ }^{13} \mathrm{C}\left\{{ }^{1} \mathrm{H}\right\} \mathrm{NMR}\left(125 \mathrm{MHz}, \mathrm{CDCl}_{3}\right): \delta=151.1\left(\mathrm{C}_{\mathrm{q}}, \mathrm{Ar}-\mathrm{C}\right), 150.3\left(\mathrm{C}_{\mathrm{q}}, \mathrm{Ar}-\mathrm{C}\right), 140.8\left(\mathrm{C}_{\mathrm{q}}, \mathrm{Ar}-\right.$ C), $139.1\left(\mathrm{C}_{\mathrm{q}}, \mathrm{Ar}-\mathrm{C}\right), 137.4(\mathrm{CH}, \mathrm{Ar}-\mathrm{C}), 135.5(\mathrm{CH}, \mathrm{Ar}-\mathrm{C}), 130.9(\mathrm{CH}, \mathrm{Ar}-\mathrm{C}), 130.6(\mathrm{CH}, \mathrm{Ar}-\mathrm{C})$, $126.1(\mathrm{CH}, \mathrm{Ar}-\mathrm{C}), 125.9(\mathrm{CH}, \mathrm{Ar}-\mathrm{C}), 125.7(\mathrm{CH}, \mathrm{Ar}-\mathrm{C}), 125.3$ (CH, Ar- $\mathrm{C}), 99.2(\mathrm{~m}, \mathrm{C}, \mathrm{Cp} * \mathrm{C}), 16.4$ $\left(d,{ }^{1} J_{\mathrm{CP}}=27.0 \mathrm{~Hz}, \mathrm{PCH}_{2} \mathrm{CH}_{3}\right), 8.6\left(\mathrm{Cp}-\mathrm{CH}_{3}\right), 8.1\left(\mathrm{~d},{ }^{2} \mathrm{~J}_{\mathrm{CP}}=3.8 \mathrm{~Hz}, \mathrm{PCH}_{2} \mathrm{CH}_{3}\right) .{ }^{31} \mathrm{P}\left\{{ }^{1} \mathrm{H}\right\} \mathrm{NMR}(121$ $\left.\mathrm{MHz}, \mathrm{CDCl}_{3}\right): \delta=21.85\left(\mathrm{~d},{ }^{1} J_{\mathrm{PRh}}=150.8 \mathrm{~Hz}\right) . \mathrm{IR}(\mathrm{KBr}): \mathrm{v}_{\mathrm{max}} / \mathrm{cm}^{-1} 3040 \mathrm{w}\left(\mathrm{v}_{\mathrm{Ar}-\mathrm{H}}\right), 2958 \mathrm{~m}\left(\mathrm{v}_{\mathrm{C}-\mathrm{H}}\right)$, $2906 \mathrm{~m}\left(\mathrm{v}_{\mathrm{C}-\mathrm{H}}\right), 1450 \mathrm{~s}, 1414 \mathrm{~m}, 1034 \mathrm{~m}, 752 \mathrm{~s}, 722 \mathrm{~m}\left(\mathrm{v}_{\mathrm{P}-\mathrm{C}}\right)$. Raman (glass capillary): $\mathrm{v}_{\mathrm{max}} / \mathrm{cm}^{-1}$ $3043 \mathrm{~m}\left(\mathrm{v}_{\mathrm{Ar}-\mathrm{H}}\right), 2915 \mathrm{~s}\left(\mathrm{v}_{\mathrm{C}-\mathrm{H}}\right), 1583 \mathrm{~s}, 1477 \mathrm{~s}, 1036 \mathrm{~s}, 774 \mathrm{~s}, 612 \mathrm{w}\left(\mathrm{v}_{\mathrm{C}-\mathrm{s}}\right), 359 \mathrm{~s}, 325 \mathrm{~s} . \mathrm{MS}\left(\mathrm{APCl}^{+}\right)$: $m / z$ (\%) $573.12(70)[\mathrm{M}+\mathrm{H}]^{+}, 455.03(20)\left[\mathrm{M}^{+}-\mathrm{PEt}_{3}\right], 119.09$ (100) $\left[\mathrm{PEt}_{3}+\mathrm{H}\right]^{+} . \mathrm{HRMS}\left(\mathrm{APCl}^{+}\right)$ $[\mathrm{M}+\mathrm{H}]^{+} \mathrm{C}_{28} \mathrm{H}_{39} \mathrm{PRhS}$ requires 573.1280, found 573.1277.

[Cp*Ir(NaphthS $\left.)_{2}\right)$ PEt $\left._{3}\right]$ (4a). This was prepared as per complex 3a using $\left[\mathrm{Cp}^{*} \mid \mathrm{ICl}_{2} \mathrm{PEt}_{3}\right]$ (150 $\mathrm{mg}, 0.29 \mathrm{mmol})$ and [Naphth $\left.(\mathrm{SH})_{2}\right](90 \mathrm{mg}, 0.46 \mathrm{mmol})$ with refluxing for $4 \mathrm{hrs}$. 4a was obtained as a yellow solid (138 mg, $0.21 \mathrm{mmol}, 75 \%)$. Crystals suitable for X-ray work were obtained from $\mathrm{CH}_{2} \mathrm{Cl}_{2}$. Anal. calcd. for $\mathrm{C}_{26} \mathrm{H}_{36} \mathrm{IPPS}_{2}$ (636.16 $\mathrm{g} \mathrm{mol}{ }^{-1}$ ): $\mathrm{C}, 49.04 ; \mathrm{H}, 5.70$. Found: C, 48.97; H, 5.81. ${ }^{1} \mathrm{H}$ NMR $\left(300 \mathrm{MHz}, \mathrm{CDCl}_{3}\right): \delta=7.83\left(\mathrm{~d},{ }^{3} \mathrm{~J}_{\mathrm{HH}}=7.3 \mathrm{~Hz}, 2 \mathrm{H}, \mathrm{Ar}-\mathrm{H}\right), 7.35\left(\mathrm{~d},{ }^{3} \mathrm{~J}_{\mathrm{HH}}\right.$ $=7.8 \mathrm{~Hz}, 2 \mathrm{H}, \mathrm{Ar}-\mathrm{H}), 6.87\left(\mathrm{dd},{ }^{3} \mathrm{~J}_{\mathrm{HH}}=7.8,7.5 \mathrm{~Hz}, 2 \mathrm{H}, \mathrm{Ar}-\mathrm{H}\right), 2.09-1.95\left(\mathrm{~m}, 6 \mathrm{H}, \mathrm{PCH}_{2} \mathrm{CH}_{3}\right), 1.43$ $\left(\mathrm{d},{ }^{4} J_{\mathrm{HP}}=1.8 \mathrm{~Hz}, 15 \mathrm{H}, \mathrm{Cp}-\mathrm{CH}_{3}\right), 0.96\left(\mathrm{dt},{ }^{3} J_{\mathrm{HP}}=15.9 \mathrm{~Hz},{ }^{3} J_{\mathrm{HH}}=7.5 \mathrm{~Hz}, 9 \mathrm{H}, \mathrm{PCH}_{2} \mathrm{CH}_{3}\right) .{ }^{13} \mathrm{C}\left\{{ }^{1} \mathrm{H}\right\}$ NMR $\left(125 \mathrm{MHz}, \mathrm{CDCl}_{3}\right): \delta=137.3\left(\mathrm{C}_{\mathrm{q}}, \mathrm{Ar}-\mathrm{C}\right), 136.5\left(\mathrm{C}_{\mathrm{q}}, \mathrm{Ar}-\mathrm{C}\right), 133.5\left(\mathrm{C}_{\mathrm{q}}, \mathrm{Ar}-\mathrm{C}\right), 127.3(\mathrm{CH}, \mathrm{Ar}-$ C), $124.3(\mathrm{CH}, \mathrm{Ar}-\mathrm{C}), 123.8(\mathrm{CH}, \mathrm{Ar}-\mathrm{C}), 94.7\left(\mathrm{~d},{ }^{2} J_{\mathrm{CP}}=2.7 \mathrm{~Hz}, \mathrm{C}_{\mathrm{q}}, \mathrm{Cp} * \mathrm{C}\right), 15.7\left(\mathrm{~d},{ }^{1} J_{\mathrm{CP}}=34.9 \mathrm{~Hz}\right.$, $\left.\mathrm{PCH}_{2} \mathrm{CH}_{3}\right), 8.3\left(\mathrm{Cp}-\mathrm{CH}_{3}\right), 6.8\left(\mathrm{~d},{ }^{2} \mathrm{~J}_{\mathrm{CP}}=2.7 \mathrm{~Hz}, \mathrm{CH}_{3}, \mathrm{PCH}_{2} \mathrm{CH}_{3}\right) .{ }^{31} \mathrm{P}\left\{{ }^{1} \mathrm{H}\right\} \mathrm{NMR}\left(121 \mathrm{MHz}, \mathrm{CDCl}_{3}\right): \delta$ $=-13.97(\mathrm{~s})$. IR $(\mathrm{KBr}): v_{\max } / \mathrm{cm}^{-1} 3034 \mathrm{w}\left(\mathrm{v}_{\mathrm{Ar}-\mathrm{H}}\right), 2962 \mathrm{w}\left(\mathrm{v}_{\mathrm{C}-\mathrm{H}}\right), 1536 \mathrm{~s}, 1192 \mathrm{~m}, 1032 \mathrm{~m}, 759 \mathrm{~s}$, 
$724 \mathrm{~m}\left(\mathrm{v}_{\mathrm{P}-\mathrm{C}}\right)$. Raman (glass capillary): $\mathrm{v}_{\max } / \mathrm{cm}^{-1} 3037 \mathrm{w}\left(\mathrm{v}_{\text {Ar-H }}\right), 2914 \mathrm{~s}\left(\mathrm{v}_{\mathrm{C}-\mathrm{H}}\right), 1537 \mathrm{~s}, 1315 \mathrm{~s}, 884 \mathrm{~s}$, $787 \mathrm{w}, 593 \mathrm{~m}\left(\mathrm{v}_{\mathrm{C}-\mathrm{S}}\right), 545 \mathrm{~m} . \mathrm{MS}\left(\mathrm{ES}^{+}\right) \mathrm{m} / \mathrm{z}(\%) 637.17(10)[\mathrm{M}+\mathrm{H}]^{+}, 518.07\left[\mathrm{M}^{\left.-\mathrm{PEt}_{3}\right] .}\right.$

[Cp*Ir(AcenapS $\left.\left.\mathbf{C}_{2}\right) \mathbf{P E t}_{3}\right]$ (4b). This was prepared as per complex 3a using $\left[\mathrm{Cp}^{*} \mid \mathrm{ICl}_{2} \mathrm{PEt}_{3}\right]$ (150 $\mathrm{mg}, 0.29 \mathrm{mmol})$ and $\left[\right.$ Acenap $\left.(\mathrm{SH})_{2}\right](101 \mathrm{mg}, 0.46 \mathrm{mmol})$ with refluxing for $6 \mathrm{hrs}$. 4b was obtained as a yellow solid (158 mg, $0.24 \mathrm{mmol}, 83 \%)$. Crystals suitable for X-ray work were obtained from $\mathrm{CH}_{2} \mathrm{Cl}_{2}$. Anal. calcd. for $\mathrm{C}_{28} \mathrm{H}_{38} \mathrm{IPPS}_{2}\left(662.17 \mathrm{~g} \mathrm{~mol}^{-1}\right): \mathrm{C}, 50.74 ; \mathrm{H}, 5.78$. Found: $\mathrm{C}, 50.67 ; \mathrm{H}, 5.89 .{ }^{1} \mathrm{H}$ NMR $\left(300 \mathrm{MHz}, \mathrm{CDCl}_{3}\right): \delta=7.84-7.69(\mathrm{~m}, 2 \mathrm{H}, \mathrm{Ar}-\mathrm{H}), 6.81\left(\mathrm{~d},{ }^{3} \mathrm{~J}_{\mathrm{HH}}=7.2\right.$ $\mathrm{Hz}, 2 \mathrm{H}, \mathrm{Ar}-\mathrm{H}$ ), $3.08\left(\mathrm{~s}, 4 \mathrm{H}, \mathrm{CH}_{2} \mathrm{CH}_{2}\right), 2.17-2.01\left(\mathrm{~m}, 6 \mathrm{H}, \mathrm{PCH}_{2} \mathrm{CH}_{3}\right), 1.50\left(\mathrm{~d},{ }^{4} J_{\mathrm{HP}}=1.9 \mathrm{~Hz}, 15 \mathrm{H}\right.$, $\left.\mathrm{Cp}_{-} \mathrm{CH}_{3}\right), 1.03\left(\mathrm{dt},{ }^{3} \mathrm{~J}_{\mathrm{HP}}=16.0 \mathrm{~Hz},{ }^{3} \mathrm{~J}_{\mathrm{HH}}=7.6 \mathrm{~Hz}, 9 \mathrm{H}, \mathrm{PCH}_{2} \mathrm{CH}_{3}\right) .{ }^{13} \mathrm{C}\left\{{ }^{1} \mathrm{H}\right\} \mathrm{NMR}\left(125 \mathrm{MHz}, \mathrm{CDCl}_{3}\right)$ : $\delta=141.2\left(\mathrm{C}_{\mathrm{q}}, \operatorname{Ar}-\mathrm{C}\right), 141.0\left(\mathrm{C}_{\mathrm{q}}, \operatorname{Ar}-\mathrm{C}\right), 132.8\left(\mathrm{C}_{\mathrm{q}}, \operatorname{Ar}-\mathrm{C}\right), 131.7\left(\mathrm{C}_{\mathrm{q}}, \mathrm{Ar}-\mathrm{C}\right), 127.7(\mathrm{CH}, \mathrm{Ar}-\mathrm{C}), 117.8$ $(\mathrm{CH}, \mathrm{Ar}-\mathrm{C}), 94.5\left(\mathrm{~d},{ }^{2} \mathrm{~J}_{\mathrm{CP}}=2.5 \mathrm{~Hz}, \mathrm{C}, \mathrm{Cp} * \mathrm{C}\right), 30.0\left(\mathrm{CH}_{2} \mathrm{CH}_{2}\right), 15.3\left(\mathrm{~d},{ }^{1} \mathrm{~J}_{\mathrm{CP}}=35.5 \mathrm{~Hz}, \mathrm{PCH}_{2} \mathrm{CH}_{3}\right)$, $8.3\left(\mathrm{Cp}-\mathrm{CH}_{3}\right), 6.9\left(\mathrm{~d},{ }^{2} \mathrm{~J}_{\mathrm{CP}}=2.8 \mathrm{~Hz}, \mathrm{PCH}_{2} \mathrm{CH}_{3}\right) .{ }^{31} \mathrm{P}\left\{{ }^{1} \mathrm{H}\right\} \mathrm{NMR}\left(121 \mathrm{MHz}, \mathrm{CDCl}_{3}\right): \delta=-14.37$ (s). IR $(\mathrm{KBr}): v_{\max } / \mathrm{cm}^{-1} 2928 \mathrm{~s}\left(\mathrm{v}_{\mathrm{C}-\mathrm{H}}\right), 1407 \mathrm{~s}, 1031 \mathrm{~s}, 760 \mathrm{~s}, 724 \mathrm{~s}\left(\mathrm{v}_{\mathrm{C}-\mathrm{P}}\right)$, 499m. Raman (glass capillary): $v_{\max } / \mathrm{cm}^{-1} 2910 \mathrm{~s}\left(\mathrm{v}_{\mathrm{C}-\mathrm{H}}\right), 1595 \mathrm{~s}, 1406 \mathrm{~s}, 1323 \mathrm{~s}, 727 \mathrm{~s}\left(\mathrm{v}_{\mathrm{C}-\mathrm{P}}\right), 579 \mathrm{~m}\left(\mathrm{v}_{\mathrm{C}-\mathrm{S}}\right), 412 \mathrm{~s}, 373 \mathrm{~s}, 177 \mathrm{~s} . \mathrm{MS}$ $\left(\mathrm{ES}^{+}\right): m / z(\%) 663.18(50)[\mathrm{M}+\mathrm{H}]^{+}, 544.08(100)\left[\mathrm{M}-\mathrm{PEt}_{3}\right]$.

[Cp*Ir(Biphens $\left.\left.\mathbf{C}_{2}\right) \mathrm{PEt}_{3}\right]$ (4c). This was prepared as per complex 3a using $\left[\mathrm{Cp}^{*} \mid \mathrm{ICl}_{2} \mathrm{PEt}_{3}\right]$ (150 $\mathrm{mg}, 0.29 \mathrm{mmol})$ and [Biphen $(\mathrm{SH})_{2}$ ] $(101 \mathrm{mg}, 0.46 \mathrm{mmol})$ with refluxing for $5 \mathrm{hrs}$. 4c was obtained as a yellow/orange solid (154 mg, $0.23 \mathrm{mmol}, 80 \%)$. Crystals suitable for X-ray work were obtained from $\mathrm{CH}_{2} \mathrm{Cl}_{2}$. Anal. calcd. for $\mathrm{C}_{28} \mathrm{H}_{38} \operatorname{IrPS}_{2}\left(662.17 \mathrm{~g} \mathrm{~mol}^{-1}\right): \mathrm{C}, 50.80 ; \mathrm{H}$, 5.78. Found: $\mathrm{C}, 50.71 ; \mathrm{H}, 5.83 .{ }^{1} \mathrm{H} \mathrm{NMR}\left(300 \mathrm{MHz}, \mathrm{CDCl}_{3}\right): \delta=7.62\left(\mathrm{dd},{ }^{3} \mathrm{~J}_{\mathrm{HH}}=7.6 \mathrm{~Hz},{ }^{4} J_{\mathrm{HH}}=\right.$ $1.3 \mathrm{~Hz}, 1 \mathrm{H}, \mathrm{Ar}-H), 7.51\left(\mathrm{dd},{ }^{3} J_{\mathrm{HH}}=7.6 \mathrm{~Hz},{ }^{4} J_{\mathrm{HH}}=1.3 \mathrm{~Hz}, 1 \mathrm{H}, \operatorname{Ar}-H\right), 7.13-7.02(\mathrm{~m}, 2 \mathrm{H}, \mathrm{Ar}-H)$, 6.95-6.88 (m, $2 \mathrm{H}, \mathrm{Ar}-\mathrm{H}), 6.85\left(\mathrm{dd},{ }^{3} \mathrm{~J}_{\mathrm{HH}}=7.5 \mathrm{~Hz},{ }^{4} J_{\mathrm{HH}}=1.5 \mathrm{~Hz}, 1 \mathrm{H}, \mathrm{Ar}-\mathrm{H}\right), 6.73\left(\mathrm{dd},{ }^{3} J_{\mathrm{HH}}=7.5\right.$ $\left.\mathrm{Hz},{ }^{4} J_{\mathrm{HH}}=1.5 \mathrm{~Hz}, 1 \mathrm{H}, \mathrm{Ar}-\mathrm{H}\right), 2.05-1.87\left(\mathrm{~m}, 3 \mathrm{H}, \mathrm{PCH}_{2} \mathrm{CH}_{3}\right), 1.73-1.56\left(\mathrm{~m}, 3 \mathrm{H}, \mathrm{PCH}_{2} \mathrm{CH}_{3}\right), 1.48$ $\left(\mathrm{d},{ }^{4} J_{\mathrm{HP}}=1.9 \mathrm{~Hz}, 15 \mathrm{H}, \mathrm{Cp}-\mathrm{CH}_{3}\right), 0.95\left(\mathrm{dt},{ }^{3} \mathrm{~J}_{\mathrm{HP}}=15.1 \mathrm{~Hz},{ }^{3} \mathrm{~J}_{\mathrm{HH}}=7.8 \mathrm{~Hz}, 9 \mathrm{H}, \mathrm{PCH}_{2} \mathrm{CH}_{3}\right) .{ }^{13} \mathrm{C}\left\{{ }^{1} \mathrm{H}\right\}$ $\operatorname{NMR}\left(125 \mathrm{MHz}, \mathrm{CDCl}_{3}\right): \delta=151.5\left(\mathrm{C}_{\mathrm{q}}, \mathrm{Ar}-\mathrm{C}\right), 150.9\left(\mathrm{C}_{\mathrm{q}}, \mathrm{Ar}-\mathrm{C}\right), 139.8\left(\mathrm{C}_{\mathrm{q}}, \mathrm{Ar}-\mathrm{C}\right), 137.2\left(\mathrm{C}_{\mathrm{q}}, \mathrm{Ar}-\right.$ C), $137.0(\mathrm{CH}, \operatorname{Ar}-\mathrm{C}), 136.1(\mathrm{CH}, \operatorname{Ar}-\mathrm{C}), 131.5(\mathrm{CH}, \mathrm{Ar}-\mathrm{C}), 131.0(\mathrm{CH}, \mathrm{Ar}-\mathrm{C}), 126.2(\mathrm{CH}, \operatorname{Ar}-\mathrm{C})$, $125.8(\mathrm{CH}, \mathrm{Ar}-\mathrm{C}), 125.4(\mathrm{CH}, \mathrm{Ar}-\mathrm{C}), 125.3(\mathrm{CH}, \mathrm{Ar}-\mathrm{C}), 99.2\left(\mathrm{~d},{ }^{2} \mathrm{~J}_{\mathrm{CP}}=2.9 \mathrm{~Hz}, \mathrm{C}_{\mathrm{q}}, \mathrm{Cp} * \mathrm{C}\right), 16.0(\mathrm{~d}$, $\left.{ }^{1} J_{\mathrm{CP}}=34.2 \mathrm{~Hz}, \mathrm{PCH}_{2} \mathrm{CH}_{3}\right), 8.1\left(\mathrm{Cp}-\mathrm{CH}_{3}\right), 7.75\left(\mathrm{~d},{ }^{2} \mathrm{~J}_{\mathrm{CP}}=3.8 \mathrm{~Hz}, \mathrm{PCH}_{2} \mathrm{CH}_{3}\right) .{ }^{31} \mathrm{P}\left\{{ }^{1} \mathrm{H}\right\} \mathrm{NMR}(121$ $\left.\mathrm{MHz}, \mathrm{CDCl}_{3}\right): \delta=-15.53$ (s). IR ( $\left.\mathrm{KBr}\right): \mathrm{v}_{\max } / \mathrm{cm}^{-1} 3040 \mathrm{w}\left(\mathrm{v}_{\mathrm{Ar}-\mathrm{H}}\right), 2958 \mathrm{w}\left(\mathrm{v}_{\mathrm{C}-\mathrm{H}}\right), 2907 \mathrm{~m}\left(\mathrm{v}_{\mathrm{C}-\mathrm{H}}\right)$, 
$1451 \mathrm{~s} 1034 \mathrm{~s}, 752 \mathrm{~s}, 724 \mathrm{~m}\left(\mathrm{v}_{\mathrm{P}-\mathrm{C}}\right)$. Raman (glass capillary): $\mathrm{v}_{\max } / \mathrm{cm}^{-1} 3043 \mathrm{~m}\left(\mathrm{v}_{\mathrm{Ar}-\mathrm{H}}\right), 2917 \mathrm{~s}\left(\mathrm{v}_{\mathrm{C}-\mathrm{H}}\right)$, $1584 \mathrm{~s}, 1479 \mathrm{~s}, 1295 \mathrm{~s}, 1036 \mathrm{~s}, 1006 \mathrm{w}$ ( $\left.\mathrm{v}_{\mathrm{P}-\mathrm{Ar}}\right), 592 \mathrm{~m}\left(\mathrm{v}_{\mathrm{C}-\mathrm{S}}\right), 362 \mathrm{~s}$. MS $\left(\mathrm{APCl}^{+}\right): \mathrm{m} / z(\%) 663.18$ (100) $[\mathrm{M}+\mathrm{H}]^{+}, 545.09$ (55) $\left[\mathrm{M}-\mathrm{PEt}_{3}\right], 119.09$ (80) $\left[\mathrm{PEt}_{3}+\mathrm{H}\right]^{+}$. HRMS $\left(\mathrm{APCl}^{+}\right)[\mathrm{M}+\mathrm{H}]^{+} \mathrm{C}_{28} \mathrm{H}_{39} \mathrm{IPPS}_{2}$ requires 663.1852 , found 663.1852 .

\section{Crystal Structure Analysis}

Data for 2, 3a, 4a and 4c were collected using a Rigaku SCX-Mini (Mo-K $\alpha$, graphite monochromator) at $-100{ }^{\circ} \mathrm{C}$; for $\mathbf{H}_{\mathbf{2}} \mathbf{b}, \mathbf{H}_{\mathbf{2}} \mathbf{d}$ using a Rigaku FRX (Mo-K $\alpha$, confocal optic) equipped with a Dectris $\mathrm{P} 200$ detector at $-100^{\circ} \mathrm{C}$ and for $\mathbf{H}_{\mathbf{2}} \mathbf{a}, \mathbf{3 b}, \mathbf{3 c}$ and $\mathbf{4 b}$ using Rigaku FRX (Mo-K $\alpha$, confocal optic) equipped with a Dectris P200 detector at $-180^{\circ} \mathrm{C}$. Intensities were corrected for Lorentz polarization, and absorption. Structures were solved by direct methods and refined by full-matrix least-squares against $F^{2}$ (SHELXL). ${ }^{\text {REF }}$ Hydrogen atoms were assigned riding isotropic displacement parameters and constrained to idealised geometries. [REF G.M. Sheldrick, Acta Cryst. 2008, A64, 112-122.]

Non-hydrogen atoms were refined anisotropically. Hydrogen atoms on carbon atoms were refined using the riding model. In the structure of $\mathbf{H}_{\mathbf{2}} \mathbf{C}$ one of the four independent molecules is highly disordered. Numerous crystallisations were attempted without success. We were unable to successfully model the disorder but since the other three independent molecules in $\mathbf{H}_{\mathbf{2}} \mathbf{C}$ are well behaved we have included this data.

Table 7-9 lists the details of data collections and refinements. CCDC 1018981-1018992 contain the supplementary crystallographic data. These X-ray data can be obtained free of charge via www.ccdc.cam.ac.uk/conts/retrieving.html or from the Cambridge Crystallographic Data centre, 12 Union Road, Cambridge CB2 1EZ, UK; fax (+44) 1223-336033; e-mail: deposit@ccdc.cam.ac.uk

Table 7. Crystallographic data for complexes 1 and 3a-c

\begin{tabular}{lllll}
\hline & $\mathbf{1}$ & $\mathbf{3 a}$ & $\mathbf{3 b}$ & $\mathbf{3 c}$ \\
\hline Empirical Formula & $\mathrm{C}_{16} \mathrm{H}_{32} \mathrm{Cl}_{2} \mathrm{OPRh}$ & $\mathrm{C}_{26} \mathrm{H}_{36} \mathrm{PRhS}_{2}$ & $\mathrm{C}_{29} \mathrm{H}_{40} \mathrm{Cl}_{2} \mathrm{PRhS}_{2}$ & $\mathrm{C}_{28} \mathrm{H}_{38} \mathrm{PRhS}_{2}$ \\
$M$ & 445.21 & 546.57 & 657.54 & 572.61 \\
\hline
\end{tabular}




\begin{tabular}{|c|c|c|c|c|}
\hline Crystal System & orthorhombic & monoclinic & triclinic & monoclinic \\
\hline Space Group & Pbca & $\mathrm{P} 2(1) / \mathrm{n}$ & $P-1$ & $\mathrm{P} 2(1) / \mathrm{n}$ \\
\hline$a[\AA]$ & $17.0730(13)$ & $8.1417(9)$ & $8.2482(12)$ & $10.5598(11)$ \\
\hline$b[\AA]$ & $15.6491(10)$ & $15.5908(18)$ & $9.0275(14)$ & $19.3610(16)$ \\
\hline$c[\AA]$ & $14.2200(10)$ & $19.840(3)$ & $20.787(3)$ & $13.0461(13)$ \\
\hline$\alpha\left[^{\circ}\right]$ & 90 & 90 & $78.352(8)$ & 90 \\
\hline$\beta\left[^{\circ}\right]$ & 90 & $98.568(7)$ & $78.709(9)$ & $95.401(3)$ \\
\hline$\nu\left[^{\circ}\right]$ & 90 & 90 & 79.883(10) & 90 \\
\hline$V\left[\AA^{3}\right]$ & $3799.3(5)$ & $2490.3(5)$ & $1471.6(4)$ & $2655.4(4)$ \\
\hline Z & 8 & 4 & 2 & 4 \\
\hline$\rho_{\text {calcd. }}\left[\mathrm{g} \mathrm{cm}^{-3}\right]$ & 1.557 & 1.458 & 1.484 & 1.432 \\
\hline$\mu\left[\mathrm{cm}^{-1}\right]$ & 1.259 & 0.928 & 0.976 & 0.874 \\
\hline Measured refln. & 18532 & 22020 & 19423 & 21811 \\
\hline Unique refln. & 3474 & 4572 & 5291 & 4872 \\
\hline$R[1>2 \sigma(I)]$ & 0.0262 & 0.0272 & 0.0817 & 0.0302 \\
\hline$w R$ & 0.0777 & 0.0615 & 0.2208 & 0.1157 \\
\hline
\end{tabular}

Table 8. Crystallographic data for complexes $\mathbf{2}$ and $4 a-c$

\begin{tabular}{lllll}
\hline & $\mathbf{2}$ & $\mathbf{4 a}$ & $\mathbf{4 b}$ & $\mathbf{4 c}$ \\
\hline Empirical Formula & $\mathrm{C}_{16} \mathrm{H}_{31} \mathrm{Cl}_{2} \mathrm{IrO}_{0.5} \mathrm{P}$ & $\mathrm{C}_{26} \mathrm{H}_{36} \mathrm{IrPS} \mathrm{P}_{2}$ & $\mathrm{C}_{28} \mathrm{H}_{38} \mathrm{IPS}_{2}$ & $\mathrm{C}_{28} \mathrm{H}_{38} \mathrm{IrPS}_{2}$ \\
$M$ & 525.52 & 635.88 & 661.92 & 661.92 \\
Crystal System & orthorhombic & monoclinic & monoclinic & monoclinic \\
Space Group & $\mathrm{Pbca}$ & $\mathrm{P} 2(1) / \mathrm{n}$ & $\mathrm{P} 2(1) / \mathrm{c}$ & $\mathrm{P} 2(1) / \mathrm{n}$ \\
$a[\AA]$ & $17.174(3)$ & $8.1474(11)$ & $8.4020(10)$ & $10.6306(11)$ \\
$b[\AA]$ & $15.618(2)$ & $15.543(2)$ & $15.6954(17)$ & $19.568(2)$ \\
$c[\AA]$ & $14.387(3)$ & $19.848(4)$ & $19.852(2)$ & $13.1691(13)$ \\
$\alpha\left[^{\circ}\right]$ & 90 & 90 & 90 & 90 \\
$\beta\left[^{\circ}\right]$ & 90 & $98.588(8)$ & $98.810(3)$ & $95.391(7)$ \\
$V\left[^{\circ}\right]$ & 90 & 90 & 90 & 90 \\
$V\left[\AA^{3}\right]$ & $3859.0(10)$ & $2485.2(7)$ & $2587.1(5)$ & $2727.3(5)$ \\
$Z$ & 8 & 4 & 4 & 4 \\
\hline
\end{tabular}




\begin{tabular}{lllll}
\hline$\rho_{\text {calcd. }}\left[\mathrm{g} \mathrm{cm}^{-3}\right]$ & 1.809 & 1.699 & 1.699 & 1.612 \\
$\mu\left[\mathrm{cm}^{-1}\right]$ & 7.292 & 5.631 & 5.413 & 5.135 \\
Measured refln. & 14170 & 22012 & 22582 & 23710 \\
Unique refln. & 3482 & 4558 & 4744 & 4912 \\
R $[\mathrm{I>2 \sigma}(\mathrm{I})]$ & 0.0235 & 0.0255 & 0.0207 & 0.0222 \\
WR & 0.0627 & 0.0534 & 0.0645 & 0.0555 \\
\hline
\end{tabular}

Table 9. Crystallographic data for $\mathbf{H}_{2} \mathbf{b}$ and $\mathbf{H}_{\mathbf{2}} \mathbf{d}$

\begin{tabular}{|c|c|c|c|c|}
\hline & $\mathrm{H}_{2} \mathrm{a}$ & $\mathrm{H}_{2} \mathrm{~b}$ & $\mathrm{H}_{2} \mathrm{C}$ & $\mathrm{H}_{2} \mathrm{~d}$ \\
\hline Empirical Formula & $\mathrm{C}_{10} \mathrm{H}_{8} \mathrm{~S}_{2}$ & $\mathrm{C}_{12} \mathrm{H}_{10} \mathrm{~S}_{2}$ & $\mathrm{C}_{12} \mathrm{H}_{10} \mathrm{~S}_{2}$ & $\mathrm{C}_{6} \mathrm{H}_{6} \mathrm{~S}_{2}$ \\
\hline$M$ & 192.29 & 218.33 & 218.33 & 142.23 \\
\hline Crystal System & monoclinic & monoclinic & triclinic & triclinic \\
\hline Space Group & $\mathrm{P} 2(1) / \mathrm{c}$ & $\mathrm{P} 2(1) / \mathrm{C}$ & $\mathrm{P}-1$ & $\mathrm{P}-1$ \\
\hline$a[\AA]$ & $6.3606(17)$ & $11.751(5)$ & $7.6315(5)$ & $7.6271(6)$ \\
\hline$b[\AA]$ & $14.849(4)$ & $11.229(3)$ & $11.6376(10)$ & $10.1076(8)$ \\
\hline$c[\AA]$ & $18.532(6)$ & $15.804(6)$ & $24.6857(18)$ & $10.1458(14)$ \\
\hline$\alpha\left[^{\circ}\right]$ & 90 & 90 & $100.640(4)$ & $95.625(13)$ \\
\hline$\beta\left[^{\circ}\right]$ & $90.307(8)$ & $110.912(12)$ & $96.102(5)$ & $111.148(9)$ \\
\hline$\nu\left[^{\circ}\right]$ & 90 & 90 & $93.939(5)$ & $108.956(10)$ \\
\hline$V\left[\AA^{3}\right]$ & $1750.3(9)$ & 1947.9(13) & $2133.7(3)$ & $669.07(15)$ \\
\hline Z & 8 & 8 & 8 & 4 \\
\hline$\rho_{\text {calcd. }}\left[\mathrm{g} \mathrm{cm}^{-3}\right]$ & 1.459 & 1.489 & 1.359 & 1.412 \\
\hline$\mu\left[\mathrm{cm}^{-1}\right]$ & 0.541 & 4.960 & 0.453 & 6.793 \\
\hline Measured refln. & 12608 & 12542 & 29581 & 10325 \\
\hline Unique refln. & 3197 & 3545 & 7716 & 2434 \\
\hline$R[I>2 \sigma(I)]$ & 0.0574 & 0.0398 & 0.1542 & 0.0516 \\
\hline WR & 0.1521 & 0.1349 & 0.4835 & 0.1406 \\
\hline
\end{tabular}

[1] A.M. Bond, R.L. Martin, Coord. Chem. Rev., 54 (1984) 23-98.

[2] R.P. Burns, C.A. McAuliffe, Adv. Inorg. Chem. Radiochem., 22 (1979) 303-348.

[3] R.P. Burns, F.P. McCullough, C.A. McAuliffe, Adv. Inorg. Chem. Radiochem., 23 (1980) 211-280. 
[4] R. Eisenberg, Structural Systematics of 1,1- and 1,2-Dithiolato Chelates, in: Prog. Inorg. Chem., John Wiley \& Sons, Inc., 2007, pp. 295-369.

[5] J.R. Phillips, J.C. Poat, A.M.Z. Slawin, D.J. Williams, P.T. Wood, J.D. Woollins, J. Chem. Soc., Dalton Trans., (1995) 2369-2375.

[6] J.D. Woollins, Chemistry of Sulfur, in: S.C. Mitchell (Ed.) Biological Interactions Of Sulfur Compounds, Taylor \& Francis, London, 1996, pp. 1-19.

[7] B.K. Teo, F. Wudl, J.H. Marshall, A. Kruger, J. Am. Chem. Soc., 99 (1977) 2349-2350.

[8] B.K. Teo, F. Wudl, J.J. Hauser, A. Kruger, J. Am. Chem. Soc., 99 (1977) 4862-4863.

[9] B.K. Teo, P.A. Snyder-Robinson, Inorg. Chem., 17 (1978) 3489-3497.

[10] B.K. Teo, P.A. Snyder-Robinson, Inorg. Chem., 18 (1979) 1490-1495.

[11] B.K. Teo, P.A. Snyder-Robinson, J. Chem. Soc., Chem. Commun., (1979) 255-256.

[12] B.K. Teo, P.A. Snyder-Robinson, Inorg. Chem., 20 (1981) 4235-4239.

[13] B.K. Teo, V. Bakirtzis, P.A. Snyder-Robinson, J. Am. Chem. Soc., 105 (1983) 6330-6332.

[14] B.K. Teo, P.A. Snyder-Robinson, Inorg. Chem., 23 (1984) 32-39.

[15] W.P. Bosman, H.G.M. van der Linden, J. Chem. Soc., Chem. Commun., (1977) 714-715.

[16] R.J. Wright, C. Lim, T.D. Tilley, Chem. Eur. J., 15 (2009) 8518-8525.

[17] A.P.S. Samuel, D.T. Co, C.L. Stern, M.R. Wasielewski, J. Am. Chem. Soc., 132 (2010) 8813-8815.

[18] P. Li, S. Amirjalayer, F. Hartl, M. Lutz, B.d. Bruin, R. Becker, S. Woutersen, J.N.H. Reek, Inorg. Chem., 53 (2014) 5373-5383.

[19] J. Ballmann, S. Dechert, S. Demeshko, F. Meyer, Eur. J. Inorg. Chem., (2009) 3219-3225.

[20] K. Charreteur, M. Kdider, J.-F. Capon, F. Gloaguen, Y.F. Pétillon, P. Schollhammer, J. Talarmin, Inorg. Chem., 49 (2010) 2496-2501.

[21] A. Albers, S. Demeshko, S. Dechert, C.T. Saouma, J.M. Mayer, F. Meyer, J. Am. Chem. Soc., 136 (2014) 3946-3954.

[22] C. Topf, U. Monkowius, G. Knör, Inorg. Chem. Commun., 21 (2012) 147-150.

[23] R. Conry, A.A. Tipton, J. Biol. Inorg. Chem., 6 (2001) 359-366.

[24] R.L. McNaughton, A.A. Tipton, N.D. Rubie, R.R. Conry, M.L. Kirk, Inorg. Chem., 39 (2000) 56975706.

[25] M. R. Malachowski, M. Adams, N. Elia, A. L. Rheingold, R. S. Kelly, J. Chem. Soc., Dalton Trans., (1999) 2177-2182.

[26] E. Erkizia, R.R. Conry, Inorg. Chem., 39 (2000) 1674-1679.

[27] P.R. Stafford, T.B. Rauchfuss, A.K. Verma, S.R. Wilson, J. Organomet. Chem., 526 (1996) 203-214.

[28] S.M. Aucott, P. Kilian, H.L. Milton, S.D. Robertson, A.M.Z. Slawin, J.D. Woollins, Inorg. Chem., 44 (2005) 2710-2718.

[29] S.M. Aucott, H.L. Milton, S.D. Robertson, A.M.Z. Slawin, G.D. Walker, J.D. Woollins, Chem. Eur. J., 10 (2004) 1666-1676.

[30] S.M. Aucott, P. Kilian, S.D. Robertson, A.M.Z. Slawin, J.D. Woollins, Chem. Eur. J., 12 (2006) 895902.

[31] C.G.M. Benson, C.M. Schofield, R.A.M. Randall, L. Wakefield, F.R. Knight, A.M.Z. Slawin, J.D. Woollins, Eur. J. Inorg. Chem., (2013) 427-437.

[32] A.J. Ashe, J.W. Kampf, P.M. Savla, Heteroat. Chem, 5 (1994) 113-119.

[33] S. Cossu, G. Delogu, D. Fabbri, P. Maglioli, Org. Prep. Proced. Int., 23 (1991) 455-457.

[34] K. Yui, Y. Aso, T. Otsubo, F. Ogura, Bull. Chem. Soc. Jpn., 61 (1988) 953-959.

[35] J. Zhao, Z. Wei, X. Zeng, X. Liu, Dalton Trans., 41 (2012) 11125-11133.

[36] E. Block, V. Eswarakrishnan, M. Gernon, G. Ofori-Okai, C. Saha, K. Tang, J. Zubieta, J. Am. Chem. Soc., 111 (1989) 658-665.

[37] I. Ara, J.R. Berenguer, E. Eguizábal, J. Forniés, E. Lalinde, A. Martín, F. Martínez, Organometallics, 17 (1998) 4578-4596.

[38] J.W. Kang, K. Moseley, P.M. Maitlis, J. Am. Chem. Soc., 91 (1969) 5970-5977.

[39] R. Xi, M. Abe, T. Suzuki, T. Nishioka, K. Isobe, J. Organomet. Chem., 549 (1997) 117-125. 
[40] S.M. Aucott, H.L. Milton, S.D. Robertson, A.M.Z. Slawin, J.D. Woollins, Heteroat. Chem, 15 (2004) 530-542.

[41] S.M. Aucott, H.L. Milton, S.D. Robertson, A.M.Z. Slawin, J.D. Woollins, Heteroat. Chem, 16 (2005) 346-351.

[42] M.L. Clarke, D.J. Cole-Hamilton, D.F. Foster, A.M.Z. Slawin, J.D. Woollins, J. Chem. Soc., Dalton Trans., (2002) 1618-1624.

[43] B.A. Paz-Michel, F.J. González-Bravo, L.S. Hernández-Muñoz, M.A. Paz-Sandoval, Organometallics, 29 (2010) 3709-3721.

[44] B. Paz-Michel, M. Cervantes-Vazquez, M.A. Paz-Sandoval, Inorg. Chim. Acta, 361 (2008) 30943102.

[45] X.-Q. Xiao, G.-X. Jin, J. Organomet. Chem., 693 (2008) 316-320.

[46] G.-L. Wang, Y.-J. Lin, O. Blacque, H. Berke, G.-X. Jin, Inorg. Chem., 47 (2008) 2940-2942.

[47] Z.-J. Yao, B. Xu, X.-K. Huo, G.-X. Jin, J. Organomet. Chem., 747 (2013) 85-89.

[48] S. Kuwata, T. Nagano, A. Matsubayashi, Y. Ishii, M. Hidai, Inorg. Chem., 41 (2002) 4324-4330.

[49] S.M. Aucott, H.L. Milton, S.D. Robertson, A.M. Slawin, J.D. Woollins, Dalton Trans., (2004) 33473352.

[50] W.L.F. Armarego, C.L.L. Chai, Purification of Laboratory Chemicals, 6th ed., ButterworthHeinemann, Oxford, 2009.

[51] L. Farrugia, J. Appl. Crystallogr., 45 (2012) 849-854. 